\title{
Lawrence Berkeley Laboratory Guidelines for Compliance with the National Environmental Policy Act and the California Environmental Quality Act
}

February 1993

\begin{tabular}{l} 
Prepared by: \\
NEPA/CEQA Program Administrator, Office for Planning and Development \\
\hline Approved by: \\
Associate Laboratory Director, Office for Planning and Development
\end{tabular}


Lawrence Berkeley Laboratory

Guidelines for Compliance with the National Environmental Policy Act and the California Environmental Quality Act

February 1993

Office for Planning and Development

Lawrence Berkeley Laboratory

University of California

Berkeley, California

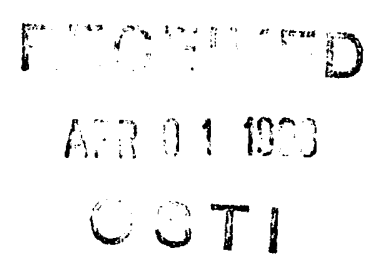




\section{TABLE OF CONTENTS}

PART A： BACKGROUND

Section 1: INTRODUCTION AND COMPLIANCE REQUIREMENTS ........... 1-1

1.1 Background ......................................................................... 1-1

1.2 Compliance Requirements........................................................... 1-2

1.3 Potential Environmental Impacts Under NEPA and CEQA............. 1-3

Section 2: $\quad$ RESPONSIBILITIES AND AUTHORITIES ................................... 2-1

2.1 Research Program and Construction Project Management................. 2-1

2.2 Administrative Coordination/Review ........................................... 2-2

2.3 NEPA/CEQA Implementation ................................................... 2-3

2.3.1 Actions that Require NEPA/CEQA Consideration ............... 2-3

2.3.2 Actions that Require Preparation of NEPA/CEQA Documentation ...................................................................... 2-4

Section 3: NEPA AND CEQA DOCUMENTATION........................................ 3-1

3.1 NEPA-Related Documentation .................................................... 3-1

3.2 CEQA-Related Documentation ..................................................... 3-4

3.3 Mitigation Monitoring Documentation ........................................... 3-6

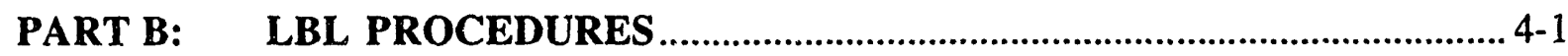

Section 4: LBL NEPA/CEQA PROCEDURES.................................................. 4-1

4.1 Planning, Scheduling, and Budgeting ............................................ 4-1

4.2 Research Programs/Projects NEPA/CEQA Review......................... 4-2

4.2.1 Procedures......................................................................... 4-3

4.3 Construction Plans/Projects NEPA/CEQA Review.......................... 4-4

4.3.1 Procedures..................................................................... 4-5

4.4 NEPA/CEQA Document Preparation............................................. 4-6

4.5 DOE/UC Review and Approval.................................................. 4-7

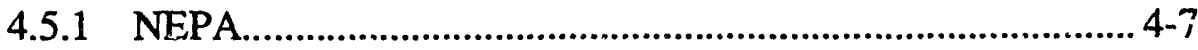

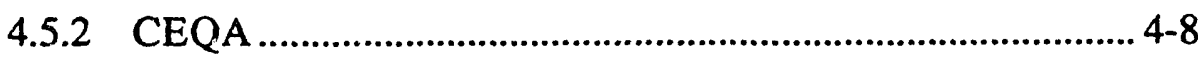

Section 5: NEPA/CEQA STATUS TRACKING ........................................... 5-1 


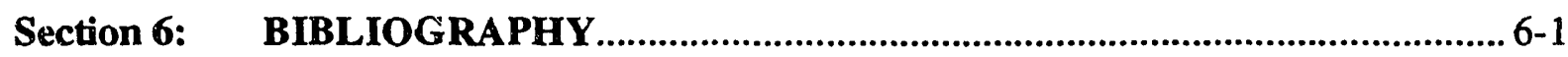

Section 7: ACRONYMS \& ABBREVIATIONS ................................................... 7-1

\section{LIST OF FIGURES AND TABLES}

Figure 1:

DOE NEPA and UC CEQA Processes.

$1-3$

Table 1:

NEPA/CEQA Documentation Responsibility for WFOs, DOE-Funded Research, and CRADAs.

Table 2:

Research Program Funding Approval Mechanisms

\section{ATTACHMENTS}

Attachment 1: $\quad$ Appendices to Subpart D of 10 CFR 1021 A1-1

Attachment 2: $\quad$ Article 19 of the CEQA Guidelines.

A2-1

Attachment 3: $\quad$ NEPA/CEQA Compliance Checklist

Attachment 4: $\quad$ Environmental Impact Classification (EIC) Form A4-1

Attachment 5: Information for NEPA/CEQA/EH\&S Review Form Information for NEPA/CEQA Review Form.

Attachment 6: $\quad$ Guidance for Writing Project Descriptions. A6-1

Attachment 7: $\quad$ Typical EA Review and Approval Schedule A7-1 
PART A: BACKGROUND

\section{Introduction and Compliance Requirements}

\subsection{Background}

The National Environmental Policy Act of 1969 (NEPA) sets forth national policy for the protection of the environment. The NEPA process is intended to help officials of the federal government make decisions that are based on an understanding of environmental consequences, and take actions that protect, restore, and enhance the environment. The California Environmental Quality Act of 1970 (CEQA) is similar to NEPA. The California legislature established CEQA to inform both state and local governmental decision-makers and the public about potential significant environmental effects of proposed activities, to identify ways to avoid or reduce environmental impacts, and to disclose to the public the reasons why a project is approved if significant environmental effects are involved.

Lawrence Berkeley Laboratory (LBL), as a government-owned and contractor-operated facility located on land leased from The Regents of the University of California (UC), complies with the provisions of both NEPA and CEQA. Since the U.S. Department of Energy (DOE) and The UC Regents have the ultimate decision-making authority on LBL activities under NEPA and CEQA, respectively, LBL staff provides information to enable both entities to determine whether LBL proposed actions will have a significant effect on the environment.

NEPA implementing regulations state that the NEPA process shall be integrated with other planning (including research and facilities planning) at the earliest possible time to insure that planning and decisions reflect environmental values, to avoid delays, and to minimize potential conflicts. CEQA guidelines also state that documentation should be prepared as early as feasible in the planning process to enable environmental considerations to influence project program and design. LBL's NEPA/CEQA Program is within the Office for Planning and Development (OPD) to ensure that environmental considerations can be fully integrated early in the planning 
process; that documents receive an independent LBL review; and that the incremental effects of each Division's activities, when added to the incremental effects of other Divisions' activities, do not result in collectively significant effects.

In order to enable LBL Managers to meet their environmental responsibilities, this document defines the responsibilities and authorities for NEPA/CEQA compliance at LBL. The document also outlines procedures for implementing NEPA and CEQA provisions. The document is intended to be a reference for Division Line Managers, Principal Investigators, and LBL support staff responsible for NEPA/CEQA compliance coordination. It also is LBL's mechanism to inform DOE and UC of the Laboratory's NEPA and CEQA compliance procedures.

\subsection{Compliance Requirements}

Both NEPA and CEQA establish procedural obligations to analyze and disclose potential environmental effects of a proposed action. To comply with NEPA, LBL follows the procedures outlined in the Council on Environmental Quality (CEQ) regulations, and the policies and procedures established by DOE for NEPA compliance. To comply with CEQA, LBL follows the State CEQA Guidelines, as issued by the California Resources Agency. LBL also follows the procedures for CEQA implementation established by The UC Regents. UC procedures are aimed at ensuring that UC meets requirements under CEQA and furthering UC's objective of being a good neighbor in the community.

Both CEQ regulations and State CEQA guidelines strongly encourage agencies to integrate NEPA and CEQA to eliminate duplication of procedures. Figure 1 shows the DOE NEPA and UC CEQA decision-making processes. Although certain aspects of the two processes differ, the addressed issues and decision processes are similar. Differences are in the content of the required NEPA and CEQA documentation, the requirement for mitigation measures, and the timing for public and agency review. At LBL steps have been undertaken to reduce the paperwork prepared for compliance with the two laws. 
DOE NEPA DECISION-MAKING PROCESS

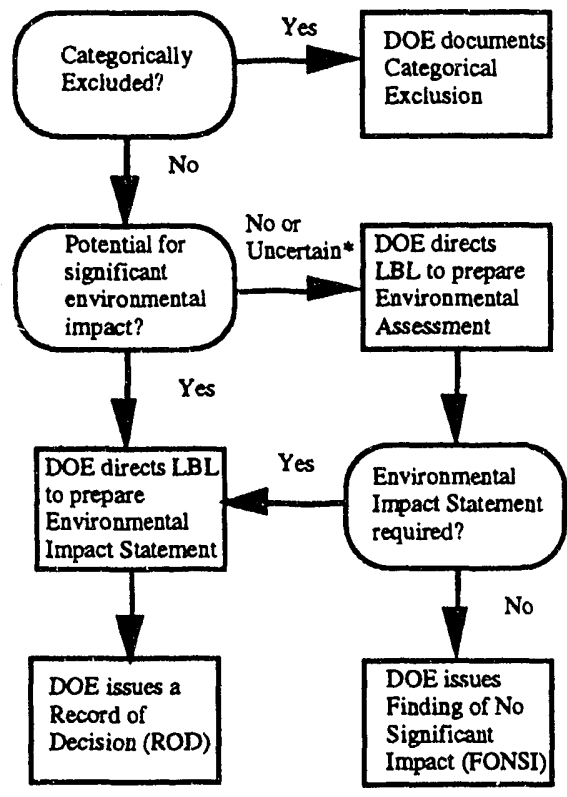

-DOE requires L.BL 10 prepare an Action Description Memorandum (ADM) for those proposed actions not specifically tisted in 10 CFR 1021, Subpart D.
UC CEQA DECISION-MAKING PROCESS

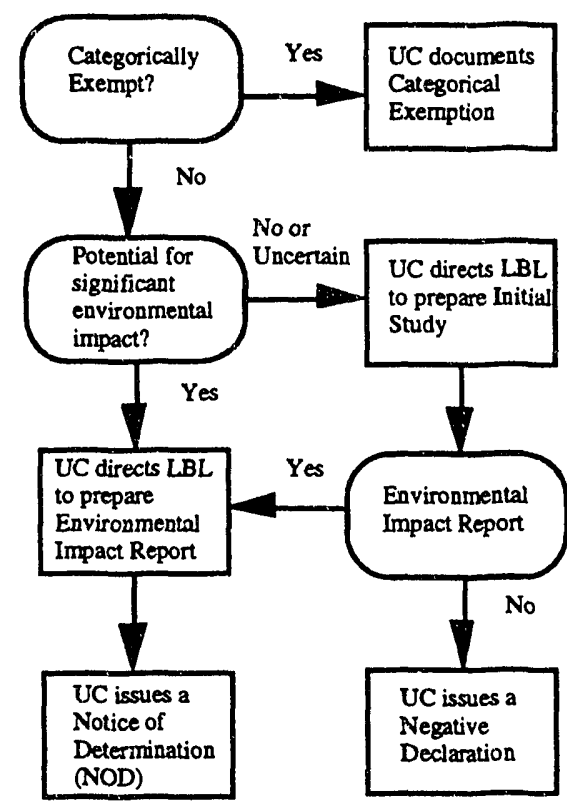

UC means Office of the President

Figure 1. DOE NEPA and UC CEQA Processes

\subsection{Potential Environmental Impacts Under NEPA and CEQA}

Areas that must be considered when determining whether a proposed action has the potential for environmental impact are

- Human health (worker and off site)

- Transportation and circulation

- Air quality

- Utilities

- Surface water

- Noise

- Ground water

- Energy

- Earth (geologic features and soil)

- Aesthetics

- Plant life

- Cultural resources

- Animal life

- Socioeconomics

Impacts may be environmentally beneficial or detrimental. Impacts may be direct, indirect, and cumulative. 
Direct impacts are caused by the action and occur at the same time and place as the action.

Indirect impacts are caused by the action and are later in time or farther removed in distance, but are still reasonably foreseeable, such as changes in the pattern of land use or population density, and related effects on air, water, and other natural systems.

Cumulative impacts are the direct and indirect effects on the environment that result from the incremental effects of the action when added to other past, present, and reasonably foreseeable future actions regardless of who undertakes them. Cumulative impacts can result from individually minor, but collectively significant, actions taking place over time.

Some actions that are proposed at LBL require permits or other agency approvals. Note that fulfilling permit and other mandated requirements does not replace the requirements to comply with NEPA and CEQA. 


\section{Responsibilities and Authorities}

\subsection{Research Program and Construction Project Management}

The primary responsibility for compliance with NEPA and CEQA at LBL resides with Division line management. Various organizations throughout the Laboratory support the NEPA/CEQA compliance activities of the Divisions.

LBL Division Line Managers meet their compliance responsibilities by:

- Knowing the scope of NEPA and CEQA documents that cover ongoing program actions and contacting the Office for Planning and Development (OPD) when an out-of-scope action is being proposed;

- Maintaining files containing original signed NEPA and CEQA Recc mmendations made by OPD or the Division, copies of NEPA/CEQA documents prepared by LBL for Division activities, and copies of signed Determinations and approvals by DOE and UC Office of the President (UCOP).

- Providing information for the NEPA and CEQÁ processes as specified for Field Task and Work for Others proposals, Conceptual Design Reports, Laboratory Directed Research and Development, and other proposals;

- Ensuring that NEPA/CEQA requirements are completed prior to beginning new activities;

- Ensuring that NEPA/CEQA-related documentation is included in the appropriate LBL Notebooks as specified in Preparation and Maintenance of LBL Notebooks, (Section 1 of the Project Notebook Procedures and Section 1 of the Function Notebook Procedures).

- Ensuring that individuals within the Division receive NEPA and CEQA training, as appropriate; and

- Assigning a Division NEPA/CEQA Coordinator who is knowledgeable in NEPA/CEQA regulations and is appropriately trained to assist the Division in meeting compliance requirements.

The Facilities Department reporting to the Associate Laboratory Director (ALD) for Operations develops Conceptual Design Reports and implements LBL's Construction Project Management Program.

- The Planning and Special Projects office, with review by the Project Coordination Committee, develops long-range project plans and identifies those construction projects that will be submitted for funding, and submits the project planning lists and project descriptions to OPD for subsequent review and recommendation to DOE and UC.

- The Project Management office reviews individual construction projects against approved NEPA and CEQA documentation. For those projects 
not covered by approved documents, the office forwards project descriptions and appropriate forms to OPD (see Section 4).

- The Project Management office monitors the progress of Environmental Assessment (EA) and Environmental Impact Report (EIR) preparation, review, and approval against the project schedule.

\subsection{Administrative Coordination/Review}

The Office for Planning and Development (OPD) coordinates and administers NEPA and CEQA implementation at LBL. It is the responsibility of OPD to:

- Review and recommend NEPA/CEQA requirements for select proposed programs, plans, and projects.

- Prepare, manage, and oversee NEPA and CEQA document preparation.

- Formulate document preparation, review and approval schedules for EAs and EIRs, in consultation with the Project Management office and Division Line Management, and monitor progress against the schedules.

- Serve as point-of-contact with UC, DOE, and regulatory agencies for document review and approval.

- Develop and oversee tracking of Mitigation Monitoring Plans.

- Maintain a computerized LBL NEPA/CEQA document tracking system that is accessible Laboratory-wide.

- Maintain files containing copies of all NEPA/CEQA Recommendations made by OPD, original signed NEPA/CEQA documents prepared by LBL, and original signed Determinations and approvals by DOE and UCOP.

- Maintain copies of inventories, reports, and formal agency consultation letters that document the locations of LBL's sensitive resources, and make this information available for use by Facilities Department and Division personnel.

- Provide NEPA/CEQA compliance training to LBL Division personnel.

- Provide input to the LBL Comprehensive Planning Calendar which includes elements of the annual NEPA/CEQA document preparation process to help ensure that environmental review is integrated into the planning and decision-making process.

The Office of Budget and Resource Planning (BRP) provides for budget submission and funding acquisition for DOE-funded research and construction projects. BRP acts as a checkpoint for ensuring the completeness of budget submissions, including NEPA/CEQA information.

The Office of Sponsored Research Administration (OSRA) provides proposal, contracting, and post-award administration support for research projects funded by or involving collaboration with a non-DOE entity or another DOE Managernent and Operating $(\mathrm{M} \& \mathrm{O})$ contractor. OSRA acts as a checkpoint 
for ensuring that all such projects receive a NEPA and CEQA recommendation.

The Environment, Health and Safety (EH\&S) Division provides technical expertise required for the preparation of NEPA/CEQA documents.

Office of Assessment and Assurance (OAA) conducts the LBL selfassessment and quality assurance programs, and audits compliance of LBL's programs. OAA performs these reviews and assessments for LBL's NEPA/CEQA program.

Laboratory Counsel provides guidance on the legal interpretation of NEPA and CEQA, and on DOE and UC implementing guidelines.

DOE and UC review LBL's NEPA and CEQA recommendations and are responsible for providing official Determinations. Although DOE has the responsibility for preparation of NEPA documents, LBL provides DOE with information and assistance in preparing the documents. LBL generally prepares the necessary CEQA documents, and UC provides guidance, review, and document approval.

\subsection{NEPA/CEQA Implementation}

The basic elements of NEPA and CEQA compliance at LBL are:

- Identification of new projects through LBL's Field Task Proposals, Conceptual Design Reports, Laboratory Directed Research and Development Program, Work for Others, and Cooperative Research and Development Agreement submissions. Completion of the appropriate forms and project descriptions necessary for adequate NEPA/CEQA review.

- Review of projects against established NEPA/CEQA criteria to determine if the projects are covered by existing NEPA/CEQA-related documentation or may require additional analysis and documenration.

- Preparation and submittal of NEPA/CEQA Recommendations to DOE and $U C$ for those projects outside the scope of existing NEPA/CEQA documentation.

- Preparation and submittal of appropriate documents based upon Determinations made by DOE and UC, such as EAs for NEPA and Initial Studies or EIRs for CEQA.

- Conduct of mitigation monitoring and implementation of mitigation measures as defined in specific Mitigation Monitoring Plans or mitigated Findings of No Significant Impact (FONSr).

\subsubsection{Actions that Require NEPA/CEQA Consideration}

$N E P A$. Any project, program, plan, or policy that is subject to DOE's control and responsibility is subject to NEPA. These actions include (1) Line Item Projects, (2) General Plant Projects, (3) Non-Capital Alteration Projects, (4) Maintenance Plans, (5) DOE-Funded Research Projects, (6) the annual 
Laboratory Directed Research and Development Program (7) Sponsored Research Projects, (8) In-House Energy Management Projects, (9) Accelerator Improvement Prujects, (10) Environmental Restoration and Waste Management Activities, and (11) Policies, such as Transportation Management Goals, that have the potential to impact the environment. LBL reviews these proposed projects and plans and makes recommendations as to the level of analysis and documentation required. LBL submits the recommendations to DOE for a NEPA Determination. The NEPA review process is not only applied to new projects, but also to continuing activities and changes in operations.

CEQA. All LBL projects are subject to a CEQA review CEQA defines "a project" as the whole of an action that has "the potential, directly or ultimately, to result in a physical change to the environment." Projects include, but are not limited to, construction and related activities, clearing or grading of land, and improvements to existing structures. Some projects are specifically exempted under state law ("Statutorily exempt"); there also exists a "general rule" that CEQA applies only to projects which have the potential for causing a significant effect on the environment. For LBL, typical projects that could have a significant effect on the environment for purposes of CEQA are: capital construction projects, some major maintenance projects such as those resulting in substantial changes to drainage patterns, long-range development plans, substantial changes in the use of facilities, renovation, asbestos removal, or construction of new laboratory space.

For all L.BL projects that are categorically exempt from CEQA or that could have a significant effect on the environment, LBL prepares a recommendation as to the level of analysis and documentation required and submits the recommendation to the UCOP for a CEQA Determination. LBL, through the implementation of the guidelines in this document, makes Determinations for all other actions that are not reviewed by the UCOP.

\subsubsection{Actions that Require Preparation of NEPA/CEQA Documentation}

With the exception of administrative activities, all proposed actions require some degree of documentation to (1) demonstrate that an appropriate NEPA/CEQA analysis has been performed and (2) officially record the NEPA/CEQA Determinations. The degree of detail and analysis necessary varies depending on the type of action and its potential environmental impacts (see Section 4).

Proposed actions at LBL fall into one of three categories:

1) Actions that are covered under the scope of existing and approved NEPA CEQA documents. Under NEPA, LBL has prepared a number of project-specific EAs that allow LBL to conduct activities that have been addressed in these documents.

Under CEQA, the LBL Site Development Plan EIR, which was prepared for LBL's Long Range Development Plan, and the Supplemental EIR for the proposed contract renewal between DOE and The UC Regents for 
operation and management of I.BL allow many proposed projects to occur without additional CEQA documentation. Additional projectspecific CEQA documents, prepared prior to and since preparation of the EIR and Supplement, allow LBL to conduct activities that are addressed in these documents.

Decisions to contuct proposed activities under existing NEPA and CEQA documents must be documented and maintained on file for internal and DOE audits, as described in Section 4.

2) Actions that are categorically excluded from the requirement for an EA or an EIS under NEPA and/or actions that have been identified by the UCOP as statutorily or categorically exempt from CEQA. Under NEPA, Categorical Exclusions are classes of actions that generally do not, individually or cumulatively, have a significant effect on the human environment and are therefore exempt from the requirement of preparing an EA or an EIS. These actions are listed in Appendix A and B to Subpart D of the DOE NEPA Regulations (see Attachment 1). The decision to appl; a Categorical Exclusion listed in Appendix B to Subpart D to a proposed action must be documented and sent to DOE for an official Determinaticn. The decision to apply a Categorical ixclusion listed in Appendix $A$ to Subpart $D$ need not be forwarded to DOE, but should be documented and filed for DOE audit.

Under CEQA, a number of actions are exempt either by statute or because they fall within classes of projects that have been determined generally not to have a significant effect on the environment. These are listed in Article 19 of the CEQA Guidelines (see Attachment 2). A decision to apply a Categorical Exemption listed in Article 19 must be sent to UCOP for an official Determination.

A Categorical Exclusion or Exemption cannot be used when there is a reasonable possibility that the activity or project will have a significant individual or cumulative effect on the environment.

3) Actions that require preparation of NEPA and CEQA documents. Proposed actions that do not fit into either of the previous two categories require preparation of an EA or an EIS under NEPA and an Initial Study or EIR under CEQA. 


\section{NEPA and CEQA Documentation}

There are six types of NEPA or NEPA-related documents that are either prepared by LBL or are prepared by DOE with assistance from LBL. These are (1) NEPA/CEQA Compliance Checklist, (2) Categorical Exclusion Recommendation/Determination, (3) Action Description Memorandum, (4) Environmental Assessment, (5) Finding of No Significant Impact, and (6) Environmental Impact Stutement.

Depending on the potential for environmental impacts from the proposed action, one or more of the following four types of CEQA documents are prepared by LBL: (1) NEPA/CEQA Compliance Checklist, (2)

Environmental Impact Classification, (3) Initial Study/Negative Declaration, and (4) Environmental Impact Report.

The following discusses the scope and content of each of these types of documents.

\subsection{NEPA-Related Documentation}

\section{NEPA/CEQA Compliance Checklist}

The NEPA/CEQA Compliance Checklist is the internal mechanism used by LBL to document the recommended NEPA documentation for proposed actions. The checklist is completed by the Division NEPA/CEQA Coordinator and maintained in the Division files so that it is available for audit by the OAA and by DOE. The NEPA/CEQA Compliance Checklist is provided as Attachment 3.

\section{Categorical Exclusion Recommendations/Determinations}

A Categorical Exclusion is a category of actions that does not individually or cumulatively have a significant effect on the human environment and that does not require the preparation of an EA or an EIS. Appendix A and Appendix B to Subpart D of the DOE NEPA regulations 10 CFR 1021 list classes of DOE actions that can be categorically excluded (see Attachment 1). Although LBL must document and maintain copies of each decision it makes to apply a Categorical Exclusion to an action, it is necessary to provide this documentation to DOE for an official Determination only for those actions listed in Appendix B. Decisions made by LBL to apply Appendix A Categorical Exclusions do not need to be forwarded to DOE.

The documentation that LBL submits to DOE to obtain an official Categorical Exclusion Determination consists of a letter to DOE that follows a prescribed format describing the proposed project and identifying which Categorical Exclusion LBL recommends and why. The DOE San Francisco Field Office (DOE/SF) references the document to prepare a Categorical Exclusion Determination. All recommendations for applying a Categorical Exclusion must contain (1) the title of the proposed action; (2) its location; (3) the proposing agency, if other than DOE; (4) a description of the 
proposed action; (5) and the Categorical Exclusion to be applied from Appendix B to subpart D of the DOE NEPA Regulations (10 CFR 1021); and (6) a statement that the proposed action meets the criteria for a Categorical Exclusion.

\section{Action Description Memorandum (ADM)}

An Action Description Mercorandum (ADM) is used to facilitate a DOE Determination of the appropriate level of NEPA documentation for proposed actions that do noi clearly fit into one of the classes of actions listed in Subpart D of the DOE NEPA regulations (10 CFR 1021). An ADM is typically prepared by LBL for DOE. An ADM should be a short document (2 pages) that contains only the information needed to make a Determination of the level of NEPA documentation required. An ADM should include (1) a description of the proposed action, (2) the proposed location for the action, and (3) the known or potential environmental issues associated with the proposed action.

\section{Environmental Assessment (EA)}

An EA is a formal public document that serves to provide sufficient evidence and analysis for determining whether to prepare an EIS or a FONSI. In practice, however, preparation of both an EA and a subsequent EIS is unlikely. If an EA is prepared, it is usually done with the expectation that a FONSI will be supported. No project at LBL has required an EIS.

An EA is a concise document with contents determined by the nature of the proposed action. The DOE Office of Energy Research (ER) has provided guidance for the preparation of EAs. An EA may include, as applicable:

- A concise description of the proposed action and its purpose;

- A description of the existing environment affected by the proposed action;

- An assessment of the probable impacts of the proposed action, including direct and indirect effects, recommended mitigation measures, and those adverse impacts that cannot be avoided should the proposal be implemented;

- An evaluation of the probable cumulative and long-term environmental effects, including any beneficial impacts;

- An assessment of the risk of credible accidents;

- A discussion of the relationship of the proposed action to any applicable Federal, State, regional, or local land use plans and policies likely to be affected; and

- An analysis of reasonable alternatives to the proposed action and their probable environmental effects.

While the NEPA regulations do not contain page limits for EAs, the Council on Environmental Quality (CEQ) has generally advised agencies to keep the length of EAs to not more than approximately 10 to 15 pages. The CEQ recognizes that "lengthy EAs" may be necessary where a proposal is complex 
and the significance of the environmental impacts difficult to determine. In general, it is LBL's goal to keep EAs below 25 pages.

The CEQ regulations require that duplication of efforts and paperwork be reduced when implementing NEPA. In support of this, another agency's document that assesses environmental concerns (e.g., an existing CEQA document) may be used in preparation of a DOE EA. In addition, background data pertinent for understanding of the assessment may be incorporated by reference.

When DOE determines that an EA must be prepared, DOE/SF notifies the State of its Determination and invites comments on the scope of the EA. Once the EA is prepared and reviewed by DOE/Headquarters (HQ), the State is given 30 days to review and comment on the document.

\section{Finding of No Significant Impact (FONSI)}

If an EA leads DOE to conclude that there is no potential for significant impacts from an action, DOE will direct LBL to prepare a draft FONSI. The FONSI restates the reasons why' an action will not have a significant effect on the environment and why an EIS, therefore, will not be prepared. After the draft FONSI is reviewed and approved by DOE, DOE publicizes the findings locally or publishes them in the Federal Register, depending on whether the action is believed to be of local or national significance. Proposed FONSIs are subjec: to public review and comment for proposals that are judged by DOE to be of particular interest/concern to the public. After a FONSI is finalized, the proposed action may proceed.

\section{Environmental Impact Statement (EIS)}

NEPA requires an EIS for all "major federal actions significantly affecting the quality of the human environment." An EIS is a detailed formal document, following a format prescribed by DOE/HQ. It provides a full and fair discussion of significant environmental impacts and informs decisionmakers and the public of the reasonable alternatives that could avoid or mitigate adverse impacts or enhance the quality of the human environment. To date, an EIS has not been required for any LBL action. The EIS process can take more than two years, so it is important that LBL and DOE begin preparation of an EIS as early as possible.

After a decision is made to prepare an EIS, a Notice of Intent (NOI) is prepared by DOE and published in the Federal Register by DOE/HQ. This initiates the public scoping period and the EIS process. Scoping is a process for determining the scope of issues to be addressed and for identifying the significant issues related to a proposed action. Scoping includes public meeting(s), with participation by DOE, LBL, and affected Federal, State, and local agencies and the interested public, and acceptance of both written and verbal comments. The scoping process culminates with the preparation of an EIS Implementation Plan (IP). The EIS IP (1) lists significant issues identified for detailed study and those that are considered beyond the scope of the EIS; (2) identifies non-NEPA environmental analysis, review, and consultation requirements; (3) schedules the NEPA process and project planning and decision-making; (4) provides a detailed outline of the EIS; (5) 
describes how the EIS will be prepared; (6) sets page-limit targets; (7) sets target dates for preparation; and (8) allocates assignments between DOE and cooperating agencies. Once approved by the Assistant Secretary for Environment, Safety, and Health, the EIS IP is made available to the public for informational purposes.

The actual preparation of the EIS involves a draft EIS, a comment period, and a final EIS. After a draft EIS is prepared, notice of its availability is posted locally and published in the Federal Register. A 45-day comment period is standard. A public hearing(s) also takes place during the comment period. Agencies with jurisdiction or special expertise relating to the project are required to comment. Nembers of the general public may also comment. LBL and DOE are expected to respond to those comments or questions at the public hearing(s) and in the final EIS. An announcement of the availability of the final EIS is published in the Federal Register immediately after completion of the EIS. No decision may be made on a proposal covered by an EIS during a 30-day waiting period following completion of the final EIS. After DOE reaches a final decision on the project, it prepares a Record of Decision (ROD), which is a public record of DOE's decision. The ROD states the decision, identifies the alternatives that were considered, and outlines mitigation measures. Upon issuance of the ROD, EIS documentation is considered complete.

\subsection{CEQA-Related Documentation}

\section{NEPA/CEQA Compliance Checklist}

The NEPA/CEQA Environmental Checklist is the internal mechanism used by $L B L$ to document the recommended CEQA documentation for proposed projecis. The checklist is completed by the Division NEPA/CEQA Coordinator and maintained in the Division files so that it is available for audit by the OAA and by the DOE. The NEPA/CEQA Compliance Checklist is provided as Attachment 3.

\section{Environmental Impact Classification}

An Environmental Impact Classification (EIC) form is a UC form that is used to determine whether a project is subject to CEQA, and if so, what type of CEQA document is required. The EIC is submitted to UCOP along with a project description and maps showing the location of the proposed project. An EIC form is provided as Attachment 4.

\section{Initial Study}

An Initial Study serves to identify potential environmental effects and to determine whether an EIR is required. If a project is not exempt from CEQA, ard it is not clear whether it would cause significant environmental impacts, LBL prepares an Initial Study. However, based on information contained in the EIC form, UCOP may determine that an EIR will clearly be required, without an Initial Study.

The primary component of an Initial Study is typically an Initial Study Environmental Checklist. An Initial Study Environmental Checklist is 
modeled after a form provided in Appendix I of the State CEQA Guidelines that requires the project proponent to provide a "yes," "no," or "maybe" response to a series of questions regarding the potential environmental impacts of a proposed project. A written explanation is required for all yes and maybe answers. An Initial Study Environmental Checklist may be all that is required if very minor potential impacts are foreseen.

In addition to the Checklist, an Initial Study consists of:

- Summary of the proposed project and its projected consequences,

- Project description,

- Project objectives,

- Project site and environmental setting,

- Environmental impacts of proposed action,

- Mitigation measures, as may be appropriate, and

- Summary and conclusions.

Negative Declaration

A Negative Declaration may be prepared for a project if the Initial Study shows that there is no substantive evidence that a project would result in significant adverse impacts, or that it is clearly possible to eliminate or mitigate impacts to less than significant levels. A Negative Declaration is a short document that provides:

- A description of the proposed project.

- The location of the project.

- A proposed finding that the project will not have a significant effect on the environment.

- An attached copy of the Initial Study documenting reasons to support the finding.

- Mitigation measures, if any, included in the project to avoid potentially significant effects.

\section{Environmental Impact Report (EIR)}

The EIR process closely follows the EIS process described above. LBL prepared a Program EIR for its Long Fange Site Development Plan, which was approved by The UC Regents in 1987. A Programmatic EIR is prepared on a series of actions that can be characterized as one large project. In 1992, LBL prepared a Supplemental EIR for the renewal of the contract between DOE and The UC Regents for operation and management of LBL.

The EIR process begins with preparation of a Notice of Preparation (NOP), which is a brief notice advising agencies that UC plans to prepare an EIR and soliciting guidance regarding the scope and content of the environmental information that should be included in the EIR. Under CEQA, scoping is an optional process in which UC meets with members of the public or agencies 
after a NOP has been issued in order to discuss environmental issues related to the project.

The actual preparation of the EIR involves an Administrative Draft EIR, a Draft EIR, and a Final EIR. The Administrative Draft EIR is an internal review document submitted to the UCOP. A Draft EIR is then prepared that incorporates comments made on the Administrative Draft EIR and is sent out for public review. A Notice of Completion (NOC) advises cognizant agencies and the public of the availability of the Draft EIR for review. The minimum comment period is 45 days. UC CEQA procedures require a public hearing during the comment period. Comments and responses to the comments are included in the Final EIR. The Final EIR is made available approximately two weeks prior to a decision by The Regents as to whether or not to certify the EIR and approve the project.

CEQA requires Findings and, if applicable, Statements of Overriding Consideration as part of the record. Findings are the conclusions made regarding the significance of a project in light of the identified impacts and mitigation measures. The conclusions support the underlying rationale used by the UC decision-maker to approve or deny the project. Findings also provide the basis for making statements of overriding consideration that the benefits are sufficient to warrant project approval even with unavoidable adverse impacts.

Once The UC Regents certify the EIR and approve the project, a Notice of Determination (NOD) is sent out to notify the public and responsible agencies that a project for which an EIR has been prepared was approved. A 30-day statute of limitations to legal challenges begins after the NOD has been filed.

\subsection{Mitigation Monitoring Documentation}

Commitments to mitigation measures as described in NEPA/CEQA documents are associated with both short-term and long-term impacts. Mitigation measures can be related to project design, such as provision for secondary containment to protect the environment in case of a spill, construction of an acoustical barrier to reduce noise levels, or relocation of a roadway to protect natural resources. Mitigation measures can be construction-related, such as specifying certain hours for construction activities to minimize noise disruption to nearby residents. Mitigation measures can last the life of the project, such as maintenance of landscaping or ground water monitoring associated with capping a hazardous waste disposal site. In some cases, mitigation measures, and the need to monitor them, can last well beyond the project, such as a requirement to maintain a newly landscaped area as part of slope stabilization.

DOE's NEPA regulations (10 CFR 1021) mandate preparation of an action plan for implementation of commitments made in an EIS/ROD to mitigate adverse environmental impacts. A Mitigation Action Plan is also required for an EA/FONSI when the FONSI is based on a commitment to take mitigative actions. The Mitigation Action Plan addresses all mitigation 
commitments expressed in the ROD or that are necessary to support the FONSI. Mitigation Action Plans receive Secretarial (EH-1) approval before the issuance of an ROD or FONSI. Until mitigation is complete, the progress made in implementing mitigative measures and the effectiveness of the Mitigation Action Plan is tracked and reported annually to DOE. The annual mitigation report should also modify the original plan to reflect new information or changed circumstances.

CEQA Section 21081.6 requires that a program be adopted that will monitor all mitigation measures, including those identified as changes in project design, to ensure that they are implemented. To meet the requirements of CEQA, LBL, as an independent organizational unit of the UC system, prepares Mitigation Monitoring Plans with the following objectives:

- To provide a means of periodically reporting o LBL management compliance with the mitigation measures.

- To provide assurance and documentation that mitigation measures are implemented as planned.

- To collect analytical data to assist the LBL administration in its determination of the effectiveness of the mitigation measures used.

- To make information on LBL's compliance with mitigation measures accessible to the public.

To help meet these objectives, the following information is included in Mitigation Monitoring Plans:

- The mitigation action,

- The organizational unit responsible for implementation of the mitigation measure,

- The organizational unit responsible for monitoring the implementation of the mitigation measure, and

- The supporting documentation for verification of compliance.

The monitoring and reporting required for NEPA and CEQA can take advantage of and incorporate existing LBL planning, development, inspection, and reporting processes at LBL, such as Title II design, the LBL Site Development Plan, and various required reports. Because monitoring of some types of mitigation measures can add substantially to the cost of the project, it is important that these measures be identified as early as possible so that they can be factored into the project cost. OPD works closely with Divisions during preparation of mitigation monitoring plans to ensure that the monitoring commitments are cost-effective and minimize additional work by LBL staff. A Mitigation Monitoring Plan was prepared for the proposed renewal of the contract between DOE and The Regents. 
PART B: LBL PROCFDURES

\section{LBL NEPA/CEQA Procedures}

LBL has developed formal procedures to ensure (1) that the NEPA and CEQA processes occur as efficiently as possible, (2) that sufficient and consistent information is provided to DOE and UCOP to allow them to determine the level of NEPA and CEQA documentation required for LBL actions, and (3) that approvals are obtained to ensure compliance with requirements.

\subsection{Planning, Scheduling, and Budgeting}

LBL Divisions should review their proposed actions for NEPA/CEQA requirements and consult with OPD as needed during early stages of project planning so that the level of environmental analysis and documentation likely to be required can be included in the project schedule and budget. Early planning will avoid or minimize delays to the start of construction and operations, avoid or minimize premature commitment of project resources, and ensure appropriate consideration of NEPA and CEQA policies. Integrating environmental review with early planning provides the opportunity to identify and consider environmental issues, alternative actions, and mitigation measures as part of project development.

NEPA/CEQA compliance must occur prior to any project activity that would (1) have an environmental impact or (2) limit the choice of reasonable project alternatives. Project activities include such actions as site clearing and preparation, earth moving and excavation, and procurement of equipment or materials. DOE NEPA regulations state the NEPA process should be complete normally in advance of, and for reaching a decision to proceed with detailed [Title II] design. Under CEQA, a project requiring UCOP action should be classified as such at the time of proposal to the UCOP to ensure concurrence in funding, planning development, and /or construction. A project not requiring UCOP concurrence must be classified before approval of the project design. Noncompliance may result in a stop-work order from DOE or UC, added costs for retrofitting, and possibly litigation. 
At LUL the sponsoring program includes a NEPA/CEQA evaluation and recommendation in the request for project funding stage. The use of this approach is consistent with the intent of NEPA and DOE's stated policy of (1) incorporating the NEPA review process in the planning and decisionmaking stages of proposed actions, and (2) placing the responsibility of NEPA review on the line organizations that carry out the projects. Appropriate training and independent audits facilitate this approach.

\subsection{Research Programs/Projects NEPA/CEQA Review}

The NEPA and CEQA review processes for research programs/projects are incorporated into established LEL Program funding/approval processes. Research projects are either partially or totally funded by DOE, by non-DOE entities, or by other M\&O contractors. Research projects include work by LBL personnel at LBL facilities, and at off-site locations. LBL's responsibility for conducting a NEPA and CEQA review for activities is dependent upon the location of the work to be performed and UC Regents action, as shown in Table 1. Note that even when LBL performs work at a non-DOE site, and non-DOE funding is involved, NEPA applies because DOE is making a decision to approve and authorize LBL to perform the work.

Table 1. NEPA/CEQA Documentation Responsibility for WFOs, DOE-Funded Research, and CRADAs

\begin{tabular}{|l|l|l|}
\hline \multicolumn{1}{|c|}{ Location of Work } & \multicolumn{1}{|c|}{ NEPA Responsibility } & \multicolumn{1}{c|}{ CEQA Responsibility } \\
\hline \hline $\begin{array}{l}\text { LBL (including Donner and Calvin } \\
\text { Labs) }\end{array}$ & LBL & LBL \\
\hline Other DOE Facility & Other DOE Facility & $\begin{array}{l}\text { LBL, if located in California } \\
\text { and UC Regents } \\
\text { approval/action is required. }\end{array}$ \\
\hline Non-DOE Federal Facility/Property & $\begin{array}{l}\text { If Categorical Exclusion, LBL } \\
\text { must prepare. Ii EA or EIS, } \\
\text { cooperative agreement for } \\
\text { preparation, or DOE adopts } \\
\text { others. }\end{array}$ & $\begin{array}{l}\text { LBL, if UC Regents } \\
\text { approval/action is required. }\end{array}$ \\
\hline $\begin{array}{l}\text { Non-Federal Facility/Property (not } \\
\text { UC campus) }\end{array}$ & $\begin{array}{l}\text { LBL, on the portion of the } \\
\text { project conducted by LBL } \\
\text { personnel, funded by DOE, or } \\
\text { using DOE equipment. }\end{array}$ & $\begin{array}{l}\text { LBL, if UC Regents } \\
\text { appsoval/action required. }\end{array}$ \\
\hline UC Campus & Same as above & Campus \\
\hline
\end{tabular}




\subsubsection{Procedures}

The following steps should be followed for those research projects for which LBL has NEPA and/or CEQA documentation responsibility.

1. As part of proposal preparation, the NEPA/CEQA Coordinator, in consultation with the Principal Investigator (PI), decides what level of NEPA and CEQA documentation, if any, will likely be required for the proposed project. This decision is documented on the NEPA/CEQA Compliance Checklist (see Attachment 3) and is reviewed and approved by the PI's Division Director or designee.

2. The Division forwards the proposal (including the completed Checklist) to the appropriate LBL administrative office, as shown in Table 2. The administrative office reviews the proposal for completeness and forwards it and the NEPA/CEQA Checklist to DOE or other funding agency, or to the LBL Director (for LDRD), as appropriate.

Table 2. Research Program Funding Approval Mechanisms

\begin{tabular}{|c|c|c|}
\hline Funding Type & Proposal Form & Administrative Office \\
\hline DOE-Funded Research & $\begin{array}{l}\text { Field Task Proposal (FTP) or } \\
\text { Field Work Proposal (FWP) }\end{array}$ & $\begin{array}{l}\text { Office of Budget and Resource } \\
\text { Planning (BRP) }\end{array}$ \\
\hline Sponsored Research & & \\
\hline Work for Others & $\begin{array}{l}\text { Request for Approval of Work } \\
\text { Proposal (AWP) }\end{array}$ & $\begin{array}{l}\text { Office of Sponsored Research } \\
\text { Administration (OSRA) }\end{array}$ \\
\hline Gift-Supported Actions & $\begin{array}{l}\text { Request for Authorization of } \\
\text { Sponsored Work (RASW) }\end{array}$ & OSRA \\
\hline $\begin{array}{l}\text { Cooperative Research and } \\
\text { Development Agreements } \\
\text { (CRADAs) }\end{array}$ & $\begin{array}{l}\text { Request for Approval of CRADA } \\
\text { Joint Work Statement (RACJWS) } \\
\text { or Project Task Statement (PTS) }\end{array}$ & OSRA \\
\hline User Agreements & User Facility forms & OSRA \\
\hline Other DOE M\&O Contractors & $\begin{array}{l}\text { Request for Approval of LBL } \\
\text { Work for Other M\&O } \\
\text { Contractors }\end{array}$ & OSRA \\
\hline $\begin{array}{l}\text { Laboratory-Funded Research } \\
\text { Laboratory Directed Research } \\
\text { and Development Program } \\
\text { (L.DRD) }\end{array}$ & LDRD Budget Request & $\begin{array}{l}\text { Office For Planning and } \\
\text { Development (OPD) }\end{array}$ \\
\hline
\end{tabular}


2a. In those cases when the Division identifies that $\mathrm{LBL}$ is not required to prepare NEPA and CEQA documentation (i.e., Boxes 1, 2 or 3 in Sections I and II of the Checklist apply), the NEPA/CEQA Coordinator also files a copy of the Checklist in the Division files as a permanent record of the NEPA/CEQA evaluation so that it is available for audit. This completes the NEPA and CEQA processes.

$2 \mathrm{~b}$. In those cases when the Division identifies that $\mathrm{LBL}$ is required to prepare NEPA and/or CEQA documentation (i.e., Boxes 4 or 5 in Section I and Boxes 4, 5, or 6 in Section II of the Checklist apply), the PI completes an "Information for NEPA/CEQAEH\&S Review" form for any work to be conducted at LBL, and an "Information for NEPA/CEQA Review" form for any off-site work that will be conducted by LBL personnel, that will be funded by DOE, or that will use DOE equipment (Attachment 5). A copy of this form(s), along with the proposal and completed Checklist, is forwarded by the NEPA/CEQA Coordinator to OPD for preparation of the necessary NEPAVCEQA documentation. This information is submitted to OPD at the same time (or as soon as possible thereafter) that the proposal and NEPA/CEQA Checklist are submitted to the LBL administrative office.

Upon receipt of this information, OPD reviews the information and concurs with or modifies the NEPA/CEQA recommendation in consultation and coordination with the Division Director and prepares the necessary documentation with the assistance of the PI, NEPA/CEQA Coordinator, and LBL support divisions. The PI reviews the documentation for technical accuracy.

3. For those projects requiring NEPA/CEQA documentation, the NEPA/CEQA documents are transmitted by OPD to the DOE Site Office and UCOP for the respective NEPA and CEQA Determinations under the signature of the Associate Laboratory Director, OPD.

4. When OPD receives the official DOE and UCOP Determinations and approvals, OPD forwards copies of these documents to the Division and the appropriate Administrative Office. Section 4.5 describes the DOE and UC document review and approval processes.

\subsection{Construction Plans/Projects NEPA/CEQA REVIEW}

Similar to the process for NEPA and CEQA review of research projects, the NEPA and CEQA review for construction projects is integrated into the established project funding process, which is managed by the Facilities Department. Most construction projects are planned well in advance of implementation and include preparation of detailed planning documents and lists of proposed activities.

These planning documents and lists provide adequate information to allow the OPD to request DOE and UCOP Determinations at the beginning of the fiscal year for many types of construction activities that will take place throughout the year. For those types of activities that are categorically excluded from NEPA or categorically exempt from CEQA, (e.g. routine 
maintenance and repair projects, In-House Energy Management Projects, Accelerator Improvement Projects) the Facilities Department provides project information to OPD at the beginning of the fiscal year, and OPD prepares the necessary NEPA and CEQA documentation and submits the documentation to DOE and UCOP.

Once DOE and UCOP Determinations are obtained, copies are forwarded by OPD to the Facilities Department. As specific projects are proposed throughout the year, the Facilities Department conducts a review to decide whether the project is covered under existing NEPA and CEQA documents or whether additional documentation is needed.

\subsubsection{Procedures}

The following is the Facilities Department process for conducting NEPA/CEQA reviews for all construction projects, except those proposed as Line Items.

1. When a project is initiated, a specific project description and scope of work is provided by the Requestor to the Facilities Department Work Input Center.

2. Once the request and authorization ( $\& \& A)$ form is signed, the project details are entered in the Facilities Database for tracking and control.

3. Entry of the project information into the database prompts a programmed comment "Checklist needed" to appear in the project record. The Checklist referred to is the "NEPA/CEQA Compliance Checklist" (see Attachment 3).

4. To decide whether or not a Checklist is needed, the NEPA/CEQA Coordinator, in consultation with the Requestor, identifies whether or not the project is covered under existing DOE-approved NEPA documentation and UC-approved CEQA documentation.

5. If the project is covered, the NEPA and CEQA document names or numbers are entered into the database, and a Checklist need not be completed.

6. If the project is not covered, a Checklist is completed by the NEPA/CEQA Coordinator and approved by the Project Manager and Division Director or designee. The Checklist recommends the level of NEPA and CEQA documentation that will likely be required for the project. A project description also is prepared by the Reguestor with input from the Project Manager following the guidance provided in "Guidance for Writing Project Descriptions" (see Attachment 6).

7. The completed Checklist and project description are forwarded by the NEPA/CEQA Coordinator to the OPD for preparation of the necessary documentation.

8. Upon receipt of this information, OPD reviews the information and concurs with or modifies the NEPA/CEQA recommendation in consultation and coordination with the Facilities Department and prepares the necessary 
documentation with the assistance of the Requestor, Project Manager, NEPA/CEQA Coordinator, and LBL support divisions.

9. The NEPA and CEQA documents are transmitted by OPD to the DOE Site Office and UCOP for the respective NEPA and CEQA Determinations under the signature of the ALD, OPD.

10. When OPD receives the official DOE and UCOP Determinations and approvals, OPD forwards a copy of the approval to the Facilities Department and the Requestor. Section 4.5 describes the DOE and UC document review and approval processes.

The NEPA/CEQA review process for Line Item projects is initiated when the Facilities Department begins preparation of the Construction Project Data Sheet (CPDS) and the Conceptual Design Report (CDR). The Project Manager contacts the OPD for assistance in preparing the CDR environmental evaluation summary, recommending the likely level of NEPA/CEQA documentation that will be prepared, and formulating the NEPA/CEQA document's preparation schedule. NEPA and CEQA aocument preparation cost are included in the budget request.

Because projects that are proposed as Line Items often involve more than minor construction and introduce new or expanded program operations to LBL, these projects often require preparation of EAs under NEPA and Initial Studies or EIRs under CEQA. The Project Manager notifies OPD when it is tirne to begin NEPA and CEQA document preparation to ensure that documeass are prepared and approved prior to Title II design (generally 1.5 to 2 years in advance of Title II). It is the Division's responsibility to ensure that the Project Manager conducts this notification.

\subsection{NEPA/CEQA Document Preparation}

DOE Order 5440.1E and SF MD 5440.1D place the responsibility for preparation of timely and adequate NEPA documents on the DOE line organizations that carry out the projects analyzed in those documents. The $O P D$, in support of LBL line organizations, prepares or pruvides technical and administrative oversight for the preparation of all NEPA and CEQA documents for LBL. These documents are prepared in coordination and consultation with LBL program, administrative, and support divisions.

$T$. pically, the OPD staff will prepare Categorical Exclusion and Exemption documentation, but will arrange for a specialized contractor to prepare EAs, EISs, Initial Studies, and EIRs. These documents provide detailed information about the project, its potential for impact to workers and the environment, and any measures that will be taken to avoid or reduce these impacts. The analysis of impacts of a proposed action is based on the potential interface of the action with the environment, and not on its programmatic need. The discussion should focus on those activities with potential for environmental impact, or should provide information to support a conclusion of no impact. 
It is important that NEPA and CEQA documents include a clear, conc se, and complete description of the proposed project because only those activities described and analyzed can be considered to have received a NEPA/CEQA review. The description should include both construction and operational aspects of the project and should be presented in nontechnical language that can be understood by the general public and nontechnical reviewers. It is also important that EAs and EIRs objectively explore project alternatives that reasonably satisfy the underlying need for the project so their comparative merits can be considered in the decision process. Preparation of these documents therefore requires technical input from individuals who have indepth knowledge about the proposed project. Throughout document preparation, the OPD consults with individuals within the proposing program who can provide descriptions of proposed operations, and other LBL Divisions who can provide information on construction details and operational and administrative procedures to ensure that the project is carried out in a safe and environmentally sound manner.

Prior to submittal to DOE/SF and UCOP, all documents are reviewed by the Division Director or designee; the Project Manager, if appropriate; and the OPD Associate Laboratory Director. After the OPD incorporates any comments, the documents are submitted to DOE/SF and UCOP under signature of the ALD, OPD.

\subsection{DOE/UC Review and Approval}

\subsubsection{NEPA}

$\mathrm{DOE} / \mathrm{SF}$ has the authority to make Determinations regarding the appropriate level of NEPA documentation for LBL proposed actions, and it is DOE/SF's responsibility to ensure that NEPA documents are technically complete and accurate before they undergo DOE/HQ review.

Each Determination made by DOE/SF that an LBL project is categorically excluded, or requires preparation of an EA, must be documented and reported to DOE/HQ Office of Energy Research (ER) and to the Office of NEPA Oversight (EH-25). EH-25 is allowed a two week nonconcurrence period to object to DOE/SFs Determination. Likewise, all EAs prepared by LBL must be reviewed and approved by DOE/SF, ER (or other DOE Program as appropriate), and $\mathrm{EH}$.

Currently, Categorical Exclusion documentation takes about one month and EAs take about one year to be approved by DOE after submittal by OPD to the DOE Berkeley Site Office (BSO). Attachment 7 shows a typical EA review and approval schedule.

OPD serves as the focal point for all communication with DOE regarding NEPA document preparation, review, and approval. CPD submits NEPA recommendations and documents to the BSO for distribution to reviewers, coordination of comments, and, if necessary, helping to expedite and track approval progress through DOE/HQ. Because of the complexity of the review and approval process, it is advised that the Division or Program 
Director for the project contact their DOE/HQ Program counterpart to help track the EA as it goes through DOE/HQ review.

Typically, the BSO forwards the EA to DOE/SF for review by Program representatives, General Counsel, the NEPA Compliance Officer, and the DOE/SF Manager. The Manager forwards the document to ER-8 for review and transmittal to ER-1. ER-1 reviews the document and transmits it to EH25. After review, EH-25 forwards the document to the ES\&H Assistant Secretary for approval. The Secretary has personally approved all programmatic and site-wide EISs, and may approve EAs or other EISs.

The State of California, and adjacent states (if DOE determines they would be affected by the proposed action), must be notified of DOE's decisions to prepare an EA, and must be provided an opportunity to review EAs before they are approved by DOE. Each EA for proposed projects is provided by DOE to host states and, as appropriate, to adjacent states for a 30-day comment period prior to EH (or Secretarial) approval.

\subsubsection{CEQA}

CEQA Determinations are made by UCOP, in consultation with the UC General Counsel. If a project is categorically exempt from CEQA, the environmental process ends with UCOP. For projects that may have significant environmental effects, LBL OPD consults with appropriate responsible and reviewing agencies. In consultation with UCOP, LBL may contact State, regional and local agencies to solicit information that might affect the decision to prepare a Negative Declaration or an EIR. The decision to prepare a Negative Declaration or an EIR is made by the UCOP and UC General Counsel, based upon information provided by LBL.

To approve a project, the UCOP or the UC Regents (depending upon the nature of the project) must determine that the project as approved will not have a significant environmental effect or that the impacts have been eliminated or mitigated to the greatest extent feasible, make findings and a statement of overriding considerations as appropriate, and issue an Notice of Determination. 


\section{NEPA/CEQA Status Tracking}

The status of NEPA and CEQA documents prepared by LBL for proposed projects is tracked on the OPD automated Tracking System. The tracking report lists the project name, the type and current status of NEPA and CEQA documentation, and additional internal LBL tracking information. This information is available through the LBL computer network to any LBL unit who requests access. A status report is provided quarterly to the DOE BSO and to LBL Management. This procedure meets corrective action requirements.

Each Division, OPD, and the Facilities Department are responsible for maintaining records of NEPA and CEQA decisions, Determinations, documents, and approvals, as follows:

Divisions are responsible for maintaining records of NEPA and CEQA decisions, Determinations, and documents for their actions. These records must be available for spot check by OPD, and audit by LBL OAA and by DOE. These files should contain:

- Original signed NEPA and CEQA Recommendations and decisions made by OPD or the Division,

- Copies of NEPA/CEQA documents prepared by LBL for Division activities, and

- Copies of signed Determinations and approvals by DOE and UCOP.

The OPD is the official repository for all NEPA and CEQA documents prepared for LBL actions. OPD is responsible for maintaining records of NEPA and CEQA recommendations and decisions made by OPD,

Determinations made by DOE and UCOP, and documents prepared by LBL. These records must be available for audit by LBL OAA and by DOE. These files should contain:

- Copies of all NEPA/CEQA Recommendations and decisions made by OPD,

- Original signed NEPA/CEQA documents prepared by LBL, and

- Original signed Determinations and approvals by DOE and UCOP.

The Facilities Department is responsible for maintaining records of NEPA and CEQA decisions, Determinations, and document approval dates for all actions initiated through the Facilities Department. This is accomplished through the department's automated tracking system showing the NEPA and CEQA Determination and document approval dates. 


\section{Bibliography}

\section{Council on Environmental Quality (CEQ)}

The National Environmental Policy Act of 1969, as amended. Public Law 91-190, 42 U.S.C. 4321-4347, January 1, 1970, as amended by Public Law 94-52, July 3, 1975, and Public Law 94-83, August 9, 1975.

Executive Office of the President. Regulations for Implementing the Procedural Provisions of the National Environmental Policy Act, 40 CFR Parts 1500-1508 (as of July 1, 1986). Reprint.

\section{Department of Energy (DOE)}

Department of Energy Order 5440.1E. National Environmental Policy Act Compliance Program.

Department of Energy 10 CFR 1021 National Environmental Policy Act Implementing Procedures and Guidelines Revocation; Final Rule and Notice. 57 Federal Register 15122. April 24, 1992.

Department of Energy San Francisco Field Office Management Directive 5440.1D. Implementation of the National Environmental Policy Act. November 24, 1992.

Office of Energy Research Guidance on the Preparation, Scope, and content of Environmental Assessments. ER NCO Communication 92-04. November $5,1992$.

DOE NEPA Guidance on Work for Others and DOE Projects. Letter from Scott Samuelson, Director, Berkeley Site Office to Martha Krebs, ALD, LBL. December 14, 1992.

\section{Lawrence Berkeley Laboratory (LBL)}

Lawrence Berkeley Laboratory Long Range Development Plan. Prepared by the Office of Planning and Development, Lawrence Berkeley Laboratory. August 1987.

\section{State of California}

The California Environmental Quality Act of 1970, Public Resources Code sections 21000 , et seq.

Guidelines for Implementation of CEQA. Office of the Secretary for Resources, 14 California Code of Regulations, Sections 15000, et seq.

\section{University of California (UC)}

Lawrence Berkeley Laboratory Site Development Plan Draft Environmental Impact Report. December, 1986.

Lawrence Berkeley Laboratory Site Development Plan Final Environmental Impact Report. August, 1987. 
Amended University Procedures for Implementation of the California Environmental Quality Act. March 17, 1989.

Procedural Handbook and Model Approach for Implementing the California Environmental Quality Act. May 1991.

Draft and Final Supplemental Environmental Impact Report for the Proposed Renewal of the Contract Between the United States Department of Energy and The Regents of the University of California for the Operation and Management of the Lawrence Berkeley Laboratory. September 1992.

Mitigation Monitoring Plan for the Proposed Renewal of the Contract Between the United States Department of Energy and The Regents of the University of California for the Operation and Management of the Lawrence Berkeley Laboratory. September 1992. 


\section{Acronyms \& Abbreviations}

\begin{tabular}{ll} 
ADM & Action Description Memorandum \\
ALD & Associate Laboratory Director \\
AWP & Request for Approval of Work Proposal \\
BRP & Office of Budget and Resource Planning \\
BSO & U.S. Department of Energy, Berkeley Site Office \\
CDR & Conceptual Design Report \\
CEQA & California Environmental Quality Act \\
CEQ & Council on Environmental Quality \\
CIEE & California Institute for Energy Efficiency \\
CPDS & Construction Project Data Sheet \\
CRADA & Cooperative Research and Development Agreements \\
DOE & U.S. Department of Energy \\
DOE/SF & U.S. Department of Energy, San Francisco Field Office \\
DOE/HQ & U.S. Department of Energy, Headquarters \\
EA & Environmental Assessment \\
EH & U.S. Department of Energy, Office of the Assistant Secretary \\
& for Environment, Safety and Health \\
EH\&S & LBL Environment, Health \& Safety Division \\
EIC & Environmental Impact Classification \\
EIR & Environmental Impact Report \\
EIS & Environmental Impact Statement \\
ER & U.S. Department of Energy, Office of Energy Research \\
ERWM & Environmental Restoration and Waste Management \\
FONSI & Finding of No Significant Impact \\
FTP & Field Task Proposal \\
FWP & Field Work Proposal \\
NP & Implementation Plan \\
LBL & Lawrence Berkeley Laboratory \\
LDRD & Laboratory Directed Research and Development \\
MEO & Management and Operating \\
\hline National Environmental Policy Act \\
Notice of Completion
\end{tabular}




$\begin{array}{ll}\text { NOD } & \text { Notice of Determination } \\ \text { NOI } & \text { Notice of Intent } \\ \text { NOP } & \text { Notice of Preparation } \\ \text { OAA } & \text { Office of Assurance and Assessment } \\ \text { OPD } & \text { Office for Planning and Development } \\ \text { OPR } & \text { Office of Planning \& Research (State Clearinghouse) } \\ \text { OSRA } & \text { Office of Sponsored Research Administration } \\ \text { PI } & \text { Principal Investigator } \\ \text { PTS } & \text { Project Task Statement } \\ \text { RACJWS } & \text { Request for Approval of CRADA Joint Work Statement } \\ \text { RASW } & \text { Request for Authorization of Sponsored Work } \\ \text { ROD } & \text { Record of Decision } \\ \text { UC } & \text { University of California } \\ \text { UCOP } & \text { UC Office of the President } \\ \text { WFO } & \text { Work for Others }\end{array}$


Appendix A to Subpart D-Categorical Exclusions Applicable to General Agency Actions

Table of Contents

A1. Routine administrative/financial/ personnel actions

A2. Contract interpretations/amendments/ modifications, clarifying or administrative

A3. Certain actions by Office of Hearings and Appeals

A4. Interpretations/rulings for existing regulations

A5. Rulemaking (interpreting/amending), no change in environmental effect

A6. Rulemakings, procedural

A7. Transfer of property, use unchanged

A8. Award of contracts for technical support/management and operation/ personal services

A9. Information gathering/data analysis/ document preparation/dissemination

A10. Reports or recommendations on nonDOE legislation

A11. Technical advice and assistance to organizations

A12. Emergency preparedness planning

A13. Procedural Orders, Notices, and guidelines

A14. Approval of technical exchange arrangements

A15. Umbrella agreements for cooperation in energy research and development

A1 Routine actions necessary to support the normal conduct of agency business, such as administrative, financial, and personnel actions.

A2 Contract interpretations, amendments, and modifications that are clarifying or administrative in nature.

A3 Adjustments, exceptions, exemptions appeals, and stays, modifications, or rescissions of orders issued by the Office of Hearings and Appeals.

A4 Interpretations and rulings with respect to existing regulations, or modifications or rescissions of such interpretations and rulings.

A5 Rulemaking interpreting or amending an existing rule or regulation that does not change the environmental effect of the rule or regulation being amended.

A6 Rulemakings that are strictly procedural, such as rulemaking (under 48 CFR part 9) establishing procedures for technical and pricing proposals and establishing contract clauses and contracting practices for the purchase of goods and services, and rulemaking (under 10 CFR part 600 ) establishing application and review procedures for, and administration, audit and closeout of, grants and cooperative agreements.

A7 Transfer, lesse, disposition, or acquisition of interests in property, if property use is to remain unchanged.

A8 Award of contracts for technical support services, management and operation of a government-owned facility, and personal services.

A9 Information gathering (including, but not limited to, literature surveys, inventories, sudits), data analysis (including computer modelling), document preparation (such as conceptual design or feasibility studies. analytical energy supply and demand studies), and dissemination (including, but not limited to, document mailings, publication, and distribution; and classroom training and informational programs), but not including site characterization or environmental monitoring. (Also see B3.1.)

A10 Reports or recommendations on legislation or rulemaking that is not proposed by DOE.

A11 Technical advice and planning assistance to international, national, state and local organizations.

A12 Emergency preparedness planning activities, including the designation of onsite evacuation routes.

A13 Administrative, organizational, or procedural Orders, Notices, and guidelines.

A14 Approval of technical exchange arrangements for information, data, or personnel with other countries or international organizations, including, but not limited to, assistance in identifying and analyzing another country's energy resources, needs and options.

A15 Approval of DOE participation in international "umbrella" agreements for cooperation in energy research and development activities that would not commi the U.S. to any specific projects or activities.

Appendix B to Subpart D-Categorical Exclusions Applicable to Specific Agency Actions

Table of Contents

B Conditions that are integral elements of the classes of actions in appendix

B1 Categorical exclusions applicable to facility operation

B1.1 Rate increases less than inflation (not power marketing, but see B4.3)

B1.2 Training exercises and simulation

B1.3 Routine maintenance/custodial services for buildings, structures, infrastructures, equipment

B1.4 Installation/modification of air conditioning systems for existing equipment

B1.5 Improvements to cooling water systems within existing building. structure

B1.6 Installation/modification of retention tanks, small basins to control runoff. spills

B1.7 Acquisition/installation/operation/ removal of communication systems, date processing equipment

B1.8 Modifications to screened water intake structures

B1.9 Placement of airway safety markings/ painting (not lighting) of existing lines, antennas

B1.10 Routine onsite storage of activated material at existing facility

B1.11 Fencing, no adverse effect on wildlife movement/surface water flow

B1.12 Detonation/burning of failed/ damaged high explosives or propellants

B1.13 Acquisition or minor relocation of access roads

B1.14 Refueling of a nuclear reactor

B1.15 Siting/construction/operation of support buildings/support structures

B1.16 Removal of asbestos from buildings
B1.17 Removal of polychlorinated biphenylcontaining items from buildings, other aboveground locations

B1.18 Siting/constmiction/operation of additional/replacement water supply wells

B1.19 Siting/construction/operation of microwave/radio communication towers

B1.20 Protect/restore/improve fish and wildlife habitat

B1.21 Noise abatement

B1.22 Relocation/demolition/disposal of buildings

B2 Categorical exclusions applicable to safety and health

B2.1 Modifications to enhance workplace habitability

B2.2 Installation of/improvements to building/equipment instrumentation (remote controls, emergency warning systems, monilors)

B2.3 Installation of equipment for personnel safety and health

B2.4 Equipment Qualification Programs

B2.5 Safety and environmental improvements of a facility, replacement/ upgrade of facility components

B3 Categorical exclusions applicable to site characterization, monitoring, and general research

B3.1 Site characterization/environmental monitoring

B3.2 Aviation activities for survey/ monitoring/security

B3.3 Research related to conservation of fish and wildlife

B3.4 Transport packaging tests for radioactive/hazsrdous material

B3.5 Tank car tests

B3.6 Indoor bench-scale research projects/ conventional laboratory operation

B3.7 Siting/construction/operation of new infill exploratory, experimental oil/gas/ geothermal wells

B3.8 Outdoor ecological/environmental research in small area

B3.9 Certain Clean Coal Technology Demonstration Program activities

B3.10 Small-scale research and development/small-scale pilot projects. at existing facility, preceding demonstration

B3.11 Outdoor tests, experiments on materials and equipment components, no source, special nuclear, or byproduct materials involved

B4 Categorical exclusions applicable to Power Marketing Administrations and to all of DOE with regard to power resources

B4.1 Contracts/marketing plans/policies for the short term

B4.2 Export of electricity over existing transmission lines

B4.3 Power marketing rate changes less than inflation

B4.4 Powcr marketing services within normal operating limits

B4.5 Temporary adjustments to river operations within existing operating constraints

B4.6 Additions/modifications to transmission facilities within previously developed area

B4.7 Adding/burying fiber optic cable 
B4.8 New electricity transmission agreements for transfer of power

B4.9 Multiple use of DOE transmission line rights-of-way

B4.10 Dismantling and removal of transmission lines

B4.11 Construction or modification of substations

B4.12 Construction of tap lines (less than 10 miles in length), not integrating major new sources

B4.13 Minor relocations of existing transmission lines (less than 10 miles in length)

B5 Categorical exclusions applicable to conservation, fossil, and renewable energy activities

B5.1 Actions to conserve energy

B5.2 Modifications to oil/gas/geothermal pumps and piping

B5.3 Modification (not expansion)/ abandonment of oil storage access/brine injection/geothermal wells, not part of site closure

B5.4 Repair/replacement of sections of pipeline within maintenance provisions

B5.5 Construction/operation of short crude oil/geothermal pipeline segments

B5.6 Oil spill cleanup operations

B5.7 Import/export natural gas, no new construction

B5.8 Import/export natural gas, new cogeneration powerplant

B5.9 Temporary exemption for electric powerplant, fuel-burning installation

B5.10 Certain permanent exemptions for electric powerplant, fuel-burning installation

B5.11 Permanent exemption for mixed natural gas and petroleum

B5.12 Permanent exemption for new peakload powerplant

B5.13 Permanent exemption for emergency operations

B5.14 Permanent exemption for meeting scheduled equipment outages

B5.15 Permanent exemption due to lack of alternative fuel supply

B5.16 Permanent exemption for new cogeneration powerplant

B6 Categorical exclusions applicable to environmental restoration and waste management activities

B6.1 CERCLA removals/similar actions under RCRA or other authorities, meeting CERCLA cost/time limits or exemptions

B6.2 Siting/construction/operation of pilotscale waste collection/treatment/ stabilization/containment facilities

B6.3 Improvements to environmental control systems

B6.4 Siting/construction/operation/ decommissioning of facility for storing packaged hazardous waste for 90 days or less

B6.5 Siting/construction/operation/ decommissioning of facility for characterizing/sorting packaged waste. overpacking waste (not high-level, spent nuclear fuel)

B6.6 Modification of facility for storing, packaging, repacking waste (not highlevel, spent nuclear fuel)
B6.7 Granting/denying petitions for allocation of commercial disposal capacity

B6.8 Modifications for waste minimization/ reuse of materials

B7 Categorical exclusions applicable to international activities

B7.1 Emergency measures under the International Energy Program

B7.2 Import/export of special nuclear or isotopic materials

B. Conditions that are Integral Elements of the Classes of Actions in Appendix B

$B$. The classes of actions listed below include the following conditions as integral elements of the classes of actions. To fit within the classes of actions listed below, a proposal must be one that would not:

(1) Threaten a violation of applicable statutory, regulatory, or permit requirements for environment, safety, and health, including requirements of DOE orders:

(2) Require siting and construction or major expansion of waste storage. disposal. recovery, or treatment facilities (including incinerators and facilities for treating wastewater, surface water, and groundwater)

(3) Disturb hazardous substances, pollutants, contaminants, or CERCLAexcluded petroleum and natural gas products that preexist in the environment such that there would be uncontrolled or unpermitted releases: or

(4) Adversely affect environmentally sensitive resources. An action may be categorically excluded if, although sensitive resources are present on a site, the action would not adversely affect those resources (e.g., construction of a building with its foundation well above a sole-source aquifer or upland surface soil removal on a site that has wetlands). Environmentally sensitive resources include, but are not limited to:

(i) Property (e.g., sites, buildings, structures. objects) of historic, archeological, or architectural significance designated by Federal, state, or local governments or property eligible for listing on the National Register of Historic Places:

(ii) Federally-listed threatened or endangered species or their habitat (including critical habitat), Federally- proposed or candidate species or their habitat, or statelisted endangered or threatened species or their habitat:

(iii) Floodplains and wetlands;

(iv) Areas having a special designation such as Federally-and state-designated wilderness areas, national parks, national natural landmarks, wild and scenic rivers,

state and Federal wildlife refuges, and marine sanctuaries;

(v) Prime agricultural lands;

(vi) Special sources of water (such as solesource aquifers, wellhead protection areas, and other water sources that are vital in a region); and

(vii) Tundra, coral reefs, or rain forests.

B1. Categorical Exclusions Applicable to Facility Operation

B1.1 Rate increases for products or services marketed by parts of DOE other than Power Marketing Administrations and approval of rate increases for non-DOE entities that do not exceed the change in the overall price level in the economy (inflation). as measured by the Gross National Product (GNP) fixed weight price index published by the Department of Commerce, during the period since the last rate increase. (Also see B4.3.)

B1.2 Training exercises and simulations (including, but not limited to, firing-range training, emergency response training, fire fighter and rescue training, and spill cleanup training).

B1.3 Routine maintenance activities and custodial services for buildings, structures, infrastructures (e.g., roads), and equipment. during which operations may be suspended and resumed. Custodial services are activities to preserve facility appearance, working conditions, and sanitation, such as cleaning, window washing, lawn mowing. trash collection, painting, and snow remova! Routine maintenance activities, corrective (that is, repair), preventive, and predictive (as defined in DOE Order 4330.4, "Maintenance Management"), are required to maintain and preserve buildings, structures, infrastructures. and equipment in a condition suitable for a facility to be used for its designated purpose. Routine maintenance may result in replacement to the extent that the replacement is in kind and is not a substantial upgrade or improvement. Routine maintenance does not include replacement of a major component that significantly extends the originally intended useful life of a facility (for example, it does not include the replacement of a reactor vessel near the end of its useful life). Routine maintenance activities include, but are not limited to:

(a) Repair of facility equipment, such as

lathes, mills, pumps, and presses:

(b) Door and window repair or replacement:

(c) Wall, ceiling, or floor repair;

(d) Reroofing:

(e) Plumbing, electrical utility, and

telephone service repair

(f) Routine replacement of high-efficiency particulate air filters;

(g) Inspection and/or treatment of currently installed utility poles;

(h) Repair of road embankments:

(i) Repair or replacement of fire protection sprinkler systems;

(j) Road and parking area resurfacing. including construction of temporary access to facilitate resurfacing:

(k) Erosion control and soil stabilization measures (such as reseeding and revegetation);

(1) Surveillance and maintenance of surplus facilities in accordance with DOE Order

5820.2. "Radioactive Waste Management";

(m) Repair and maintenance of transmission facilities, including replacement of conductors of the same nominal voltage. poles, circuit breakers, transformers. capacitors, crossarms, insulators, and downed transmission lines, in accordance. where appropriate, with 40 CFR Part 761 (Polychlorinated Biphenyls Manufacturing. Processing, Distribution in Commerce, and Use.Prohibitions):

(n) Routine testing and calibration of facility components, subsystems, or portable 
equipment (including but not limited to. control valves, in-core monitoring devices, transformers, capscitors); and

(o) Routine decontamination of spot or minor contamination on the surfaces of equipment, rooms, hot cells, or other interior surfaces of buildings (by such activities as wiping with rags, using strippable latex, and minor vacuuming) and removal of contaminated intact equipment (labware) and other materials (e.8., gloves and other clothing).

B1.4 Installation or modification of air conditioning systems required for temperature control for operation of existing equipment.

B1.5 Minor improvements to cooling water systems within an existing building or structure if the improvements would not: (1) Create new sources of water or involve new receiving waters: (2) adversely affect water withdrawals or the temperature of discharged water; or (3) increase introductions of or involve new introductions of hazardous substances, pollutants, contaminants, or CERCLA-excluded petroleum and natural gas products.

B1.6 Installation or modification of retention tanks or small (normally under one acre) basins and associated piping and pumps for existing operations to control runoff or spills (such as under 40 CFR part 112). Modifications include, but are not limited to, installing liners or covers.

B1.7 Acquisition, installation, operation and removal of communication systems, data processing equipment, and similar electronic equipment.

B1.8 Modifications to screened water intake structures that result in intake velocities and volumes that are within existing permit limits.

B1.9 Placement of airway safety markings and painting (but excluding lighting) of existing electrical transmission lines and antenna structures in accordance with Federal Aviation Administration standards.

B1.10 Routine, onsite storage at an existing facility of activated equipment and material (including lead) used at that facility, to allow reuse after decay of radioisotopes with short half-lives.

B1.11 Installation of fencing, including that for border marking, that will not adversely affect wildlife movements or surface water flow.

B1.12 Detonation or burning of explosives or propellants that failed in outdoor tests (i.e. duds) or were damaged in outdoor tests (e.g. by frecturing) in outdoor areas designated and routinely used for explosive detonation or burning under an existing permit issued by state or local authorities.

B1.13 Acquisition or minor relocation of existing access roads serving existing facilities if the traffic they are to carry will not change substantially.

B1.14 Refueling of an operating nuclear reactor, during which operations may be suspended and then resumed.

B1.15 Siting, construction, and operation of small-scale support buildings,and support structures (including prefabricatód buildings and trailers) and/or small-scale modifications of existing buildings or structures, within or contiguous to an already developed area (where site utilities and roads are available). Covered support buildings and structures (and/or modifications) include those for office purposes; parking; cafeteria services; education and training; visilor reception; computer and data processing services; employee health services or recreation activities; routine maintenance activities; storage of supplies and equipmen for administrative services and routine maintenance activities: security (including security posts); fire protection; and similar support purposes, but excluding facilities for waste storage activities, except as provided in other parts of this appendix.

B1.16 Removal of asbestos-containing materials from buildings in accordance with 40 CFR part 81 (National Emission Standards for Hazardous Air Pollutants), subpart $M$ (National Emission Standard for Asbestos); 40 CFR part 763 (Asbestos), subpart G

(Asbestos Abatement Projects); 29 CFR part 1910, subpart I (Personal Protective Equipment), \& 1910.134 (Respiratory

Protection); subpart $Z$ (Toxic and Hazardous Substances), \& 1910.1001 (Asbestos, tremolite. anthophyllite and actinolite); and 29 CFR part 1926 (Safety and Health Regulations for Construction), subpart D (Occupational Health and Environmental Controls). \& 1928.58 (Asbestos, tremolite, anthophyllite. and actinolite), other appropriate Occupational Safety and Health Administration standards in title 29, chapter XVII of the CFR, and appropriate state and local requirements, including certification of removal contractors and technicians.

B1.17 Removal of polychlorinated biphenyl (PCB)-containing items, such as transformers or capacitors, PCB-containing oils flushed from transformers, PCB-flushing solutions, and PCB-containing spill materials from buildings or other aboveground locationr in accordance with 40 CFR part 761 (Polychlorinated Biphenyls Manufacturing. Processing, Distribution in Commerce, and Use Prohibitions)

B1.18 Siting, construction, and operation of additional water supply wells (or replacement wells), within an existing well field, if there would be no drawdown other then in the immediate vicinity of the pumping well, no resulting long-term decline of the water table, and no degradation of the aquifer from the new or replacement wells.

B1.19 Siting, construction, and operation of microwave and radio communication towers and associated facilities, if the towers and associated facilities would not be in an area of great visual value.

B1.20 Small-scale activities undertaken to protect, restore, or improve fish and wildlife habitat, fish passage facilities (such as fish ladders or minor diversion channels), or fisheries.

B1.21 Minor noise abatement measures. such as construction of noise barriers and installation of noise control materials.

B1.22 Relocation of buildings (including. but not limited to, trailers and prefabricated buildings) to an already developed area where site utilities and roads are available and demolition and subsequent disposal of buildings and support structures (including. but not limited to, smoke stacks and parking lot surfaces).
B2. Categorical Exclusions Applicable to Safety and Health

B2.1 Modifications of an existing structure to enhance workplace habitability (including, but not limited to: improvements to lighting, radiation shielding, or heating/ ventilating/air conditioning and its instrumentation; and noise reduction).

B2.2 Installation of, or improvements to. building and equipment instrumentation (including, but not limited to, remote control panels, remote monitoring capability, alarm and surveillance systems, control systems to provide automatic shutdown, fire detection and protection systems, announcement and emergency warning systems, criticality and radiation monitors and alarms, and safeguards and security equipment).

B2.3 Installation of, or improvements to, equipment for personnel safety and health, including, but not limited to, eye washes, safety showers, radiation monitoring devices. and fumehoods and associated collection and exhaust systems, provided that emissions would not incresse.

B2.4 Development and implementation of Equipment Qualification Programs (under DOE Order 5460.6. "Safety of DOE-owned Nuclear Reactors") to augment information on safety-related system components or to improve systems reliability.

B2.5 Safety and environmental improvements of a facility, including replacement ind upgrade of facility components, that do not result in a significant change in the expected useful life, design capacity, or function of the facility and during which operations may be suspended and then resumed. Improvements may include, but are not limited to: Replacement/upgrade of control valves, in-core monitoring devices, facility air filtration systems, or substation transformers or capacitors; addition of structural bracing to meet earthquake standards and/or gustain high wind loading. and replacement of aboveground or belowground tanks and related piping if there is no evidence of leakage, based on testing that meets performance requirements in 40 CFR part 280, subpart D (40 CFR part 280.40). This includes activities taken under RCRA. subtitle I: 40 CFR part 265, subpart J; 40 CFR pert 280, subparts B, C, and D; and other applicable state, Federal and local requirements for underground storage tanks. These actions do not include rebuilding or modifying substantial portions of a facility. such as replacing a reactor vessel.

B3. Categorical Exclusions Applicable to Site Characterization, Monitoring, and General Research

B3.1 Site characterization and environmental monitoring, including siting. construction, operation, and dismantlement or closing (abandonment) of characterization and monitoring devices and siting. construction, and operation of a small-scale laboratory building or renovation of a room in an existing building for sample analysis. Activities covered include, but are not limited to, site characterization and environmental monitoring under CERCLA and RCRA. Specific activities include, but are not limited 
(a) Geological, geophysical (such as gravity, magnetic, electrical, seismic, and radar), geochemical, and engineering surveys and mapping, including the establishment of survey marks;

(b) Installation and operation of field instruments, such as stream-gauging stations or flow-measuring devices, telemetry systems, geochemical monitoring tools, and geophysical exploration tools;

(c) Drilling of wells for sampling or monitoring of groundwater or the vadose (unsaturated) zone, well logging, and installation of water-level recording devices in wells:

(d) Aquifer response testing;

(e) Installation and operation of ambient air monitoring equipment;

(f) Sampling and characterization of water, soll, rock, or contaminants:

(g) Sampling and characterization of water effluents, air emissions, or solyd waste streams;

(h) Installation and operation of meteorological towers and associated activities, including assessment of potential wind energy resources;

(i) Sampling of flora or fauna; and

(j) Archeological, historic, and cultural resource identification in compliance with 38 CFR part 800 and 43 CFR part 7.

B3.2 Aviation activities for survey, monitoring, or security purposes that comply with Federal Aviation Administrstion regulations.

B3.3 Research, inventory, and information collection activities that are directly related to the conservation of fish and wildlife resources and that involve only negligible animal mortality, habltat destruction, or propulation reduction.

B3.4 Drop, puncture, water-immersion, thermal, and fire tests of transport packaging for radioactive or hazardous materials to certify that designs meet the requirements of 48 CFR \& 173.411 and 173.412 and requirements of severe accident conditions as specifled in 10 CFR 871.73.

B3.5 Tank car tests under 49 CFR part 170 (including, but not limited to, tests of safety rellef devices, pressure regulators, and thermal protection systems).

B3.6 Induor bench-scale research projects and conventional laboratory operations (for example, preparation of chemical atandards and sample analysis) within exioting laboratory facilitios.

B3.7 Siting, construction, and operation of new infill exploratory and experimental (test) oll, gas, and geothermal wells, which are to be drilled in a geological formation that has existing operating wells.

B3.8 Outdoor ecological and other environmental research (Including siting. construction, and operation of a emall-scale laboratory building or renovation of a room in an exleting building for semple analyoio) in a small area (generally less than flve acres) that would not result in any permanent change to the ecosystem.

B3.9 Demonstration actions proposed under the Clean Coal Technology

Demonstration Program, if the actlons would not increase the quantity or rate of air emiselong. These demonstration actions in-', de, but are not limited to: (a) Test treatment of 20 percent or less of the throughput product (solid, liquid, or gas) generated at an existing and fully operationa coal combustion or coal utlization facility;

(b) Addition or replacement of equipmen for reduction or control of sulfur dioxide. oxides of nitrogen, or other regulated substances that requires only minor modification to the existing structures at an existing coal combiation or coal utilization facility for which the existing use remains unchanged; and

(c) Addition or replacement of equipment for reduction or control of sulfur dioxide. oxides of nitrogen, or other regulated substances that involves no permanent change in the quantity or quality of cosl bein burned or used and involves no permanent change in the capacity factor of the coal combuation or coal utilization facillty, other than for demonotration purposes of two yeare or less in duration.

B3.10 Small-scale research and development projects and small-scale pilot projects conducted (for generally less than two years) to verify a concept before demonstration actions, performed in an existing structure not requiring major modification.

B3.11 Outdoor tests and experiments for the development, quality assurance, or rellability of materials and equipment (including, but not limited to, weapon system components), under controlled conditions that would not involve source, special nuclear, or byproduct materials. Covered activities may include, but are not limited to burn tests (such as tests of electric cable fire resistance or the combustion characteristics of fuels), impact tests (such as pneumatic - jector tests uaing earthen embankments or concrete slabs desigmated and routinely used for that purpose), or drop, puncture, waterimmeraion, or thermal tests.

B4. Categorical Exalusions Applicable to Power Marketing Administrations and to all of DOE with Regand to Puwer Resources

B4.1 Establishment and implemen itlon of short-term contracts, marketing plans. policles, annual operating plans, allocation plans, or acquisition of excess power, the terms of any of which do not exceed five yeare and would not cause changes in the normal operating limits of generating projects, and if transmisesion would occur over exiating tranminiosion systems.

B4.2 Export of electricity over existing transmission lines as provided by section 202(e) of the Federal Power Act.

B4.3 Changes in rates for electric power, power transmission, and other products or services provided by a Power Marketing Administration thet are based on a change in revenue requirements that does not exceed the change in the overall price level in the economy (inflation), as measured by the GNP fixed weight price index published by the Department of Commerce, during the pertod alnce the last rate adjustment for that product or aervice or. If the rate change does exceed the change in the GNP fixed weight price index, the rate change would have no potential for affecting the operation of power generation resources.

B4.4 Power marketing services, including storage, load shaping, seasonal exchanges, or other similar activities if the operations of generating projects would remain within normal operating limits.

B4.5 Temporary adjustments to river operations to accommodate day-to-day river fluctuations, power demand changes, fish and wildlife conservation program requirements, and other external events if the adjustments would occur within the existing operating constraints of the particular hydrosystem operation.

B4.6 Additions or modifications to transmission facilities that would not affect the environment beyond the previously developed facility area, including tower modifications, changing insulators, and replacement of poles, circuit breakers, transformers, and crossarms.

B4.7 Adding fiber optic cable to transmission structures or burying fiber optic cable in existing transmission line rights-ofway.

B4.8 New electricity transmission agreements, and modifications to existing transmission arrangements, to use a transmission facility of one aystem to transfer power of and for another system, if no new generation projects would be involved and no physical changes in the transmission system would be made beyond the previously developed facillity area.

B4.9 Grant or denial of requests for multiple use of a transmission facility rightsof-way, such as grazing permits and crossing egreements, including electric lines, water lines, and drainage culverts.

B4.10 Dismantling and removal of transmiseion lines and right-of-way abandonment.

B4.11 Construction or modification of substations (including owitching stations) with power dellvery at $230 \mathrm{kV}$ or below and/ or support facilities, that would not involve the construction or relocation of more then 10 miles of transmisalon lines or the integration of a major new resource.

B4.12 Construction of tap lines (less than 10 milles in length) that are not for the Integration of major new sources of generation into a main tranemiseion systom.

B4.13 Minor relocations of exiating transmission lines (less than 10 miles in length) made to enhance existing environmental and land use condjtions. Such actions Include relocations to avold right-ofway encroachments, resolve conflict with property development, accommodate road/ highway construction, allow for the construction of facilities such as canale and pipelines, or reduce exiating impacts to environmentally sensitive areas.

B5. Categorical Exclusions Applicable to Conservation, Fossil, and Renewable Energy Activities

B5.1 Actlons to conserve energy, demonstrate potentlal energy conservation. and promote energy-efficlency thet do not increase the indoor concentratione of potentially harmful substances. These actions may involve financial and technical assistance to individuais (such as bullders, owners, consultants, designero) organizations (such as utilitles), and state and local governments. Covered actione include, but are not limited to: programmed 
lowering of thermostat settings, placement of timers on hot water heaters, installation of solar hot water systems, installation of efficient lighting, improvements in generator efficiency and appliance efficiency ratings, development of energy-efficient manufacturing or industrial practices, and small-scale conservation and renewable energy research and development and pilot projects. The actions could involve building renovations or new structures in commercial residential, agricultural, or industrial sectors. These actions do not include rulemakings. standard-settings, or proposed DOE legislation.

B5.2 Modifications to oil, gas, and geothermal facility pump and piping configurations, manifolds, metering systems, and other instrumentation that would not change design process flow rates or affect permitted air emissions.

B5.3 Modification (but not expansion) or abandonment (including plugging), which is not part of site closure, of crude oil storage access wells, brine injection wells, or geothermal wells.

B5.4 Repair or replacement of sections of a crude oil, produced water, brine, or geothermal pipeline, if the actions are determined by the Army Corps of Engineers to be within the maintenance provisions of a DOE permit under section 404 of the Clean Water Act.

B5.5 Construction and subsequent operation of short offsite crude oil or geothermal pipeline segments between DOE facilities and existing commercial crude oil transportation, storage, or refining facilities, or geothermal transportation or storage facilities, within a single industrial complex. if the pipeline segments are within existing rights-of-way.

B5.6 Removal of oil and contaminated materials recovered in oil spill cleanup operations in accordance with the National Oil and Hazardous Substances Pollution Contingency Plan (NCP) and disposed of in accordance with local contingency plans in accordance with the NCP.

B5.7 Approval of new authorization or amendment of existing authorization to import/export natural gas under section 3 of the Natural Gas Act that does not involve new construction and only requires operational changes, such as an increase in natural gas throughput, change in transportation, or change in storage operations.

B5.8 Approval of new authorization or amendment of existing authorization to import/export natural gas under section 3 of the Natural Gas Act invalving a new cogeneration powerplant (as defined in the Powerplant and Industrial Fuel Use Act) within or adjacent to an existing industrial complex and requiring less than 10 miles of new gas pipeline.

B5.9 The grant or denial of any temporary exemption under the Powerplant and Industrial Fuel Use Act of 1978 for any electric powerplant or major fuel-burning installation

B5.10 The grant or denial of any permanent exemption under the Powerplan and Industrial Fuel Use Act of 1978 of any existing electric powerplant or major fuel- burning installation, other than an exemption under (1) section 312 (c) relating to cogeneration, (2) section $312(1)$ relating to scheduled equipment outages, (3) section 312 (b) relating to certain state or local requirements, and (4) section $312(8)$ relating to certain intermediate load powerplants.

B5.11 The grant or denial of a permanent exemption from the prohibitions of Title II of the Powerplant and Industritil Fuel Use Act of 1878 for any new electric powerplant or major fuel-burning installation to permit the use of certain fuel mixtures containing natural gas or petroleum.

B5.12 The grant or denial of a permanent exemption from the prohibitions of Title Il of the Powerplant and Industrial Fuel Use Act of 1978 for any new peak-load powerplant.

B5.13 The grant or denial of a permanen exemption from the prohibitions of Title Il of the Powerplant and Industrial Fuel Use Act of 1978 for any new electric powerplant or major fuel-burning installation to permit operation for emergency purposes only.

B5.14 The grant or denial of a permanen exemption from the prohibitions of Titles II and III of the Powerplant and Industrial Fuel Use Act of 1978 for any new or existing major fuel-burning installation for purposes of meeting scheduled equipment outages not to exceed an average of 28 days per year over a three-year period.

B5.15 The grant or denial of a permanent exemption from the prohibitions of Title II of the Powerplant and Industrial Fuel Use Act of 1978 for any new major fuel-burning installation which, in petitioning for an exemption due to lack of alternate fuel supply at a cost which does not substantially exceed the cost of using imported petroleum, certifies that it will be operated less than 800 hours per year.

B5.16 The grant or denial of a permanent exemption from the prohibitions of Title II of the Powerplant and Industrial Fuel Use Act of 1978 for any new cogeneration powerplant. B6. Categorical Exclusions Applicable to Environmental Restoration and Waste Management Activities

B6.1 Removal actions under CERCLA (including those iaken as final response actions and those taken before remedial action) and removal-type actions similar in scope under RCRA and other authorities (including those taken as partial closure actions and those taken before corrective action), including treatment (e.g..

incineration), recovery, storage, or disposal of wastes at existing facilities currently handling the type of waste involved in the removal action. These actions will meet the CERCLA regulatory cost and time limits or satisfy either of the two regulatory exemptions from those cost and time limits (National Contingency Plan, 40 CFR part 300) These actions include, but are not limited to:

(a) Excavation or consolidation of contaminated soils or materials from drainage channels, retention basins, ponds, and spill areas that are not receiving contaminated surface water or wastewater, if surface water or groundwater would not collect and if such actions would reduce the spreed of, or direct contact with, the contamination; (b) Removal of bulk containers (for example, drums, barrels) that contain or may contain hazardous substances, pollutants, contaminants, CERCLA-excluded petroleum or natural gas products, or hazardous wastes (designated in 40 CFR part 261), if such actions would reduce the likelihood of spillage, leakage, fire, explosion, or exposure to humans, animals, or the food chain;

(c) Removal of an underground storage tank including its associated piping and underlying containment systems in compliance with RCRA, subtitle I; 40 CFR part 285, subpart J; and 40 CFR part 280. subparts $F$ and $G$ if such action would reduce the likelihood of spillage, leakage, or the spread of, or direct contact with.

contamination;

(d) Repair or replacement of leaking containers:

(e) Capping or other containment of contaminated soils or sludges if the capping or containment would not affect future groundwater remediation and if needed to reduce migration of hezardous substances pollutants, contaminants, or CERCLAexcluded petroleum and natural gas products into soil, groundwater, gurface water, or air;

(f) Drainage or closing of man-made surface impoundments if needed to maintain the integrity of the structures:

(g) Confinement or perimeter protection using dikes, trenches, ditches, or diversions if needed to reduce the spread of, or direct contact with, the contamination

(h) Stabilization, but not expansion, of berms, dikes, impoundments, or caps if needed to maintain integrity of the structures:

(i) Drainage controls (for example, run-off or run-on diversion) if needed to reduce offsite migration of hazardous substances. pollutants, contaminants, or CERCLAexcluded petroleum or natural gas products or to prevent precipitation or run-off from other sources from entering the release area from other areas:

(j) Segregation of wastes that react with one another to result in adverse environmental impacts;

(k) Use of chemicals and other materials to neutralize the $\mathrm{pH}$ of wastes;

(1) Use of chemicals and other materials to retard the spread of the release or to mitigate its effects if the use of such chemicals would reduce the spread of, or direct contact with the contamination;

(m) Installation and operation of gas ventilation systems in soil to remove methane or petroleum vapors without any toxic or radioactive co-contaminants if appropriate filtration or gas treatment is in place;

(n) Installation of fences, warning signs, or other security or site control precautions if humans or animals have access to the release; and

(o) Provision of an alternative water supply that would not create new water sources if necessary immediately to reduce exposure to contaminated household or industrial use water and continuing until such time as local authorities can satisfy the need for a permanent remedy.

B6.2 The siting, construction, and operation of temporary (generally less than 2 years) pilot-8cale waste cqllection and 
fovilities and/or packaging and unpacking facilities (that may include characterization 2perations) for all waste other than high-level ; vaste or spent nuclear fuel (except for storaze of packaged hazardous waste for 90 days or less or for longer periods as provided for in 40 CFR pan. 292.34 (d). (e). or (f). (Refer to B6.4; also see B6.5 and B6.8.)

Appendix $D$ to Subpart $D-C l a s s e s$ of Actions That Normally Require EIS:

\section{Table of Contents}

D1. Major System Acquisitions

D2. Siting/construction/operation/ decommissioning of nuclear fuel reprocessing facilities

Ds. Siting/conatruction/operation/ decommisis...ing of uranium enrichment facilities

D4. Siting/construstion/operation/ decommissioning of reactors

D5. Main transmission system additions

D6. Integrating transmission facilities

D7. Allocation of power for five years or longer, major new generation resources/ major loads,'-aujor changes in operation of power generation resources

D8. Import/export of natural ges, involving major new facilities

D9. Import/export of natural gas, involving aignivivant operational change

D10. Siting/construction/operation of major high-level waste treatment, storage. disposal facilities

D11. Siting/construction/expansion of waste disposal facility for transuranic waste
D12. Siting/construction/operation of incinerators (other than research and development, other than nonhazardous solid waste)

D1 Major System Acquisitions, as designated by DOE Order 4240.1.

"Designation of Major System Acquisitions and Major Projects."

D2 Siting, construction, operation, and decommissioning of nuclear fuel reprocessing facilities.

D3 Siting, construction, operation, and decommissioning of uranium enrichment facilities.

D4 Siting, consiruction, operation, and decommissioning of power reactors, nuclear material production reactors, and test and research reactors.

D5 Main transmission system additions (that is, additions of new transmission lines) to a Power Marketing Administration's main transmission grid.

D6 Integrating transmission facilities (that is, transmission system additions for integreting major new sources of generation into a Power Marketing Administration's main grid)

D7 Extabiishmen nd inplementation of contracts, polsvies, marketing plans, or allecation plans for periocis of five years or longer that involve (1) the addition of major (greater than 50 average megawatts) new generation resources. $(?)$ service to discrete, major (10 average megawatts or more over a 12 month period) new losds, or (3) major changes in the operating parameters of power generation resources.

D8 Approval or disapproval of an application to import/export natural gas under section 3 of the Natural Gas Act involving major new natural gas pipeline construction or related facilities, such as construction of new liquid natural gas (LNG) terminals, regasification or storage facilities. or a significant expansion of an existing pipeline or related facility or LNG terminal. regasification, or storage facility.

D9 Approval or disapproval of an application to import/export natural gas under section 3 of the Natural Gas Act involving a significant operational change, such as a major increase in the quantity of liquid natural gas imported or exported.

D10 Siting, construction, operation, and decommissioning of major treatment, storage. and/or disposal facilities for high-level waste and/or opent nuclear fuel, such as apent fuel storage facilities and geologic repositories.

D11 Siting, construction (or expansion). and operation of a disposal facility for transuranic (TRU) waste and TRU mixed waste (TRU waste also containing hazardous waste as designated in 40 CFR part 261).

D12 Siting, construction, and operation of Incinerators, other than research and development incinerators or incinerators for nonhezardous solid waste (as designated in 40 CFR part 261.4(b)).

[FR Doc. 92-0245 Fuled 4-23-82; 8:45 am] ULUMO CODE CABO-O1-M 


\section{Article 19. Cafegorical Exemptions}

15300.

Section 21084 of the Public Resources Code requires these Guidelines to include a list of classes of projects which have been determined not to have a significant effect on the environment and which shall, therefore, be exempt from the provisions of CEQA.

In response to that mandate, the Secretary for Resources has found that the following classes of projects listed in this article do not have a significant effect on the environment, and they are declared to be categorically exempt from the requirement for the preparation of environmental documents.

Note:

Authority cited: Sections 21083 and 21087, Public Resources Code; Reference: Section 21084, Public Resources Code.

\section{1.}

Section 21080 of the Public Resources Code exempts from the application of CEQA those projects over which public agencies exercise only ministerial authority. Since ministerial projects are already exempt, categorical exemptions should be applied only where a project is not ministerial under a public agency's statutes and ordinances. The inclusion of activities which may be ministerial within the classes and examples contained in this article shall not be construed as a finding by the Secretary for Resources that such an activity is discretionary.

\section{Note:}

Authority cited: Sections 21083 and 21087, Public Resources Code; Reference: Section 21084, Public Resources Code.

\section{2 .}

(a) Location. Classes 3,4,5, 6, and 11 are qualified by consideration of where the project is to be located - a project that is ordinarily insignificant in its impact on the environment may in a particularly sensitive environment be significant. Therefore, these classes are considered to apply all instances, except where the project may impact on an environmental resource of hazardous or critical concern where designated, precisely mapped, and officially adopted pursuant to law by federal, state, or local agencies.

(b) Cumulative Impact. All exemptions for these classes are inapplicable when the cumulative impact of successive projects of the same type in the same place, over time is significant - for example, annual additions to an existing building under Class 1 .

(c) Significant Effect. A categorical exemption shall not be used for an activity where there is a reasonable possibility that the activity will have a significant effect on the environment due to unusual circumstances.

Note:

Authority cited: Sections 21083 and 21087, Public Resources Code; Reference: Section 21084, Public Resources Code.

\section{Categorical Exemptions}

\section{Relation to Ministerial Projects}

\section{Exceptions}


List of Categorical

Exemptions

A public agency may, at any time, request that a new class of categorical exemptions be added, or an existing one amended or deleted. This request must be made in writing to the Office of Planning and Research and shall contain detailed information to support the request. The granting of such request shall be by amendment to these Guidelines.

Note:

Authority cited: Sections 21083 and 21087, Public Resources Code; Reference: Section 21084, Public Resources Code.

\section{4.}

Application By Public Agencies

Each public agency shall, in the course of establishing its own procedures, list those specific activities which fall within each of the exempt classes, subject to the qualification that these lists must be consistent with both the letter and the intent expressed in the classes. Public agencies may omit from their implementing procedures classes and examples that do not apply to their activities, but they may not require EIRs for projects described in the classes and examples in this article except under the provisions of Section 15300.2.

Note:

Authority cited: Sections 21083 and 21087, Public Resources Code; Reference: Section 21084, Public Resources Code.

15301.

Existing Facilities Class 1 consists of the operation, repair, maintenance, or minor alteration of existing public or private structures, facilities, mechanical equipment, or topographical features, involving negligible or no expansion of use beyond that previously existing, including but not limited to:

(a) Interior or exterior alterations involving such things as interior partitions, plumbing, and electrical conveyances;

(b) Existing facilities of both investor and publicly-owned utilities used to provide electric power, natural gas, sewerage, or other public utility services;

(c) Existing highways and streets, sidewalks, gutters, bicycle and pedestrian trails, and similar facilities except where the activity will involve removal of a scenic resource including a stand of trees, a rock outcropping, or an historic building;

(d) Restoration or rehabilitation of deteriorated or damaged structures, facilities, or mechanical equipment to meet current standards of public health and safety, unless it is determined that the damage was substantial and resulted from an environmental hazard such as earthquake, landslide, or flood;

(e) Additions to existing structures provided that the addition will not result in an increase of more than:

(1) 50 percent of the floor area of the structures before the addition, or 2,500 square feet, whichever is less; or

(2) 10,000 square feet if:

(A) The project is in an area where all public services and facilities are available to allow for maximum development permissible in the General Plan and

(B) The area in which the project is located is not environmentally sensitive.

(f) Addition of safety or health protection devices for use during construction of or in conjunction with existing structures, facilities, or mechanical equipment, or topographical features including navigational devices;

(g) New copy on existing on and off-premise signs; 
New Construction or Conversion of Small Structures

(d) Conversion of overhead electric utility distribution system facilities to underground including connection to existing overhead electric utility distribution lines where the surface is restored to the condition existing prior to the undergrounding.

Note:

Authority cited: Sections 21083 and 21087, Public Resources Code; Reference: Section 21084, Public Resources Code.

15303.

Class 3 consists of construction and location of limited numbers of new, small facilities or structures; instal- lation of small new equipment and facilities in small structures; and the conversion of existing small structures from one use to another where only minor modifications are made in the exterior of the structure. The numbers of structures described in this section are the maximum allowable on any legal parcel or to be associated with a project within a two year period. Examples of this exemption include but are not limited to:

(a) Single-family residences not in conjunction with the building of two or more such units. In urbanized areas, up to three single-family residences may be constructed or converted under this exemption.

(b) Apartments, duplexes, and similar structures, with no more than four dwelling units if not in conjunction with the building or conversion of two or more such structures. In urbanized areas, exemption applies to single apartments, duplexes, and similar structures designed for not more than six dwelling units if not constructed in conjunction with the building or conversion of two or more such structures.

(c) Stores, motels, offices, restaurants, and similar small commercial structures not involving the use of significant amounts of hazardous substances, if designed for an occupant two or more such structures. In urbanized areas, the exemption also applies to commercial buildings on sites zoned for such use, if designed for an occupant load of 30 persons or less if not constructed in conjunction with the building of four or more such structures and if not involving the use of significant amounts of hazardous substances.

(d) Water main, sewage, electrical, gas, and other utility extensions of reasonable length to serve such construction.

(e) Accessory (appurtenant) structures including garages, carports, patios, swimming pools, and fences.

Note:

Authority cited: Sections 21083 and 21087, Public Resources Code; Reference: Section 21084, Public Resources Code.

15304.

Minor Alterations Class 4 consists of minor public or private alterations in the condition of land, water, to Land and/or vegetation which do not involve removal of mature, scenic trees except for forestry and agricultural purposes. Examples include but are not limited to:

(a) Grading on land with a slope of less than 10 percent, except that grading shall not be exempt in a waterway, in any wetland, in an officially designated (by federal, state, or local government action) scenic area, or in officially mapped areas of severe geologic hazard;

(b) New gardening or landscaping;

(c) Filling of earth into previously excavated land with material compatible with the natural features of the site; 
(d) Minor alterations in land, water, and vegetation on existing officially designated wildlife management areas or fish production facilities which result in improvement of habitat for fish and wildlife resources or greater fish production;

(e) Minor temporary use of land having negligible or no permanent effects on the environment, including carnivals, sales of Christmas trees, etc;

(f) Minor trenching and backfilling where the surface is restored;

(g) Maintenance dredging where the spoil is deposited in a spoil area authorized by all applicable state and federal regulatory agencies;

(h) The creation of bicycle lanes on existing rights-of-way.

Note:

Authority cited: Sections 21083 and 21087, Public Resources Code; Reference: Section 21084, Public Resources Code.

15305.

Class 5 consists of minor alterations in land use limitations in areas with an average slope of less than $20 \%$, which do not result in any changes in land use or density, including but not limited to:

(a) Minor lot line adjustments, side yard, and set back variances not resulting in the creation of any new parcel;

(b) Issuance of minor encroachment permits;

(c) Reversion to acreage in accordance with the Subdivision Map Act.

Note:

Authority cited: Sections 21083 and 21087, Public Resources Code; Reference: Section 21084, Public Resources Code.

\section{6.}

Class 6 consists of basic data collection, research, experimental management, and resource evaluation activities which do not result in a serious or major disturbance to an environmental resource. These may be strictly for information gathering purposes, or as part of a study leading to an action which a public agency has not yet approved, adopted, or funded.

Note:

Authority cited: Sections 21083 and 21087, Public Resources Code; Reference: Section 21084, Public Resources Code.

15307.

Class 7 consists of actions taken by regulatory agencies as authorized by state law or local ordinance to assure the maintenance, restoration, or enhancement of a natural resource where the regulatory process involves procedures for protection of the environment. Examples include but are not limited to wildlife preservation activities of the State Deparment of Fish and Game. Construction activities are not included in this exemption.

Note:

Authority cited: Sections 21083 and 21087, Public Resources Code: Reference: Section 21084. Public Resources Code.

Minor Alterations in Land Use Limitations

\section{Information Collection}

Actions by

Regulatory Agencies

for Protection of Natural Resources 
15308.

Actions by Class 8 consists of actions taken by regulatory agencies, as authorized by state or Regulatory Agencies for Protection of local ordinance, to assure the maintenance, restoration, enhancement. or protection of the environment where the regulatory process involves procedures for protection the Environment of the environment. Construction activities and relaxation of standards allowing environ- mental degradation are not included in this exemption.

Note:

Authority cited: Sections 21083 and 21087. Public Resources Code: Reference: Section 21084, Public Resources Code; International Longshoremen's and Warehousemen's Union v. Board of Supervisors, (1981) 116 Cal. App. 3d 265.

Discussion:

This section reflects the ruling in International Longshoremen's and Warehousemen's Union v. Board of Supervisors, (1981) 116 Cal. App. 3d 265. That decision ruled that the use of categorical exemption Class 8 was improper for a change in a county air pollution rule that allowed a doubling of the emissions of oxides of nitrogen. The court followed the ruling in Wildlife Alive 1 . Chickering, (1976) $18 \mathrm{Cal}$. 3d 190 that provided that where there is a reasonable possibility that a project or activity may have a significant effect on the environment, an exemption is improper.

15309.

Inspections Class 9 consists of activities limited entirely to inspections, to check for performance of an operation, or quality, health, or safety of a project, including related activities such as inspection for possible mislabeling, misrepresentation, or adulteration of products.

Note:

Authority cited: Sections 21083 and 21087, Public Resources Code; Reference: Section 21084, Public Resources Code.

15310.

Loans Class 10 consists of loans made by the Department of Veterans Affairs under the Veterans Farm and Home Purchase Act of 1943, mortgages for the purchase of existing structures where the loan will not be used for new construction and the purchase of such mortgages by financial institutions. Class 10 includes but is not limited to the following examples:

(a) Loans made by the Department of Veterans Affairs under the Veterans Farm and Home Purchase Act of 1943.

(b) Purchases of mortgages from banks and mortgage companies by the Public Employees Retirement System and by the State Teachers Retirement System.

Note:

Authority cited: Sections 21083 and 21087, Public Resources Code; Reference: Section 21084, Public Resources Code.

\section{1.}

Accessory Class 11 consists of construction, or placement of minor structures accessory to Structures (appurtenant to) existing commercial, industrial, or institutional facilities, including but not limited to:

(a) On-premise signs;

(b) Small parking lots; 
(c) Placement of seasonal or temporary use items such as lifeguard towers, mobile food units, portable restrooms, or similar items in generally the same locations from time to time in publicly owned parks, stadiums, or other facilities designed for public use.

Note:

Authority cited: Sections 21083 and 21087, Public Resources Code; Reference: Section 21084, Public Resources Code.

15312.

Class 12 consists of sales of surplus govemment property except for parcels of land located in an area of statewide, regional, or areawide concenn identified in Section 15206 (b)(4). However, even if the surplus property to be sold is located in any of those areas, its sale is exempt if:

(a) The property does not have significant values for wildlife habitat or other environmental purposes, and

(b) Any of the following conditions exist:

(1) The property is of such size, shape, or inaccessibility that it is incapable of independent development or use; or

(2) The property to be sold would qualify for an exemption under any other class of categorical exemption in these Guidelines; or

(3) The use of the property and adjacent property has not changed since the time of purchase by the public agency.

Note:

Authority cited: Sections 21083 and 21087, Public Resources Code; Reference Section 21084, Public Resources Code.

\section{3.}

Class 13 consists of the acquisition of lands for fish and wildlife conservation purposes including preservation of fish and wildlife habitat, establishing ecological reserves under Fish and Game Code Section 1580, and preserving access to public lands and waters where the purpose of the acquisition is to preserve the land in its natural condition.

Note:

Authority cited: Sections 21083 and 21087, Public Resources Code; Reference: Section 21084, Public Resources Code.

\section{4.}

Class 14 consists of minor additions to existing schools within existing school grounds where the addition does not increase original student capacity by more than $25 \%$ or ten classrooms, whichever is less. The addition of portable classrooms is included in this exemption.

\section{Note:}

Authority cited: Sections 21083 and 21087, Public Resources Code: Reference: Section 21084, Public Resources Code.

\section{5.}

Class 15 consists of the division of property in urbanized areas zoned for residential, commercial. or industrial use into four or fewer parcels when the division is in conformance with the General Plan and zoning, no variances or exceptions are required,

\section{Acquisition of Lands for Wildlife Conservation Purposes}

\section{Surplus}

Government Property Sales
Minor Additions to Schools

\section{Minor Land Divisioṇs}


all services and access to the proposed parcels to local standards are available, the parcel was not involved in a division of a larger parcel within the previous 2 years, and the parcel does not have an average slope greater than 20 percent.

Note:

Authority cited: Sections 21083 and 21087, Public Resources Code: Reference: Section 21084. Public Resources Code.

15316.

Transfer of

Ownership of Land in Order to Create

Parks

Class 16 consists of the acquisition or sale of land in order to establish a park where the land is in a natural condition or contains historic sites or archaeological sites and either:

(a) The management plan for the park has not been prepared, or

(b) The management plan proposes to keep the area in a natural condition or preserve the historic or archaeological site. CEQA will apply when a management plan is proposed that will change the area from its natural condition or significantly change the historic or archaeological site.

Note:

Authority cited: Sections 21083 and 21087, Public Resources Code; Reference: Section 21084, Public Resources Code.

15317.

Open Space Contracts or Easements

Designation of Wilderness Areas

Annexations of Existing Facilities and Lots for Exempt Facilities

Class 17 consists of the establishment of agricultural preserves, the making and renewing of open space contracts under the Williamson Act, or the acceptance of easements or fee interests in order to maintain the open space character of the area. The cancellation of such preserves, contracts, interests, or easements is not included and will normally be an action subject to the CEQA process.

Note:

Authority cited: Sections 21083 and 21087, Public Resources Code; Reference: Section 21084, Public Resources Code.

15318.

Class 18 consists of the designation of wilderness areas under the California Wilderness System.

Note:

Authority cited: Sections 21083 and 21087, Public Resources Code; Reference: Section 21084, Public Resources Code.

15319.

Class 19 consists of only the following annexations

(a) Annexations to a city or special district of areas containing existing public or private structures developed to the density allowed by the current zoning or pre-zoning of either the gaining or losing environmental agency whichever is more restrictive, provided, however, that the extension of utility services to the existing facilities would have a capacity to serve only the existing facilities.

(b) Annexations of individual small parcels of the minimum size for facilities exempted by Section 15303, New Construction or Conversion of Small Structures. 
Educational or Training Programs Involving No Physical Changes

Normal Operations of Facilities for Public Gatherings
Cal. App. 3d 546. There the cour noted that enforcement actions are taken long after the public agency, or possibly the State Legislature, has exercised its discretion to set standards governing a certain kind of activity.

\section{2.}

Class 22 consists of the adoption, alteration, or termination of educational or training programs which involve no physical alteration in the area affected or which involve physical changes only in the interior of existing school or training structures. Examples include but are not limited to:

(a) Development of or changes in curriculum or training methods.

(b) Changes in the grade structure in a school which do not result in changes in student transportation.

Note:

Authority cited: Sections 21083 and 21087, Public Resources Code; Reference: Section 21084, Public Resources Code.

15323.

Class 23 consists of the normal operations of existing facilities for public gatherings for which the facilities were designed, where there is a past history of the facility being used for the same or similar kind of purpose. For the purposes of this section, "past history" shall mean that the same or similar kind of activity has been occurring for at least three years and that there is a reasonable expectation that the future occurrence of the activity would not represent a change in the operation of the facility. Facilities included within this exemption include, but are not limited to. racetracks, stadiums, convention centers, auditoriums, amphitheaters, planetariums, swimming pools, and amusement parks.

Note:

Authority cited: Sections 21083 and 21087, Public Resources Code; Reference: Section 21084, Public Resources Code.

\section{Discussion:}

This section clarifies what is meant by the term "a past history of the facility being used for the same kind of purpose." The section relates the concept of past history to public expectations for use of the facility in the future. Where the facility has been used for a particular purpose for several years and people expect the use to continue in the future, continuation of that use would not represent a change in the environmental conditions. For example, if a county fair had included a stock car racing meet for each of three consecutive years, people living in the area would have come to expect that the county fair would involve stock car racing in the future. Continuing racing activity would not represent a substantial change in the environment from what people had come to expect. However, in Lewis v. 17th District Agricultural Ass' $n$ (1985) 165 Cal. App. 3d 823, the court found that the existence of residential areas near a racetrack constituted "unusual circumstances" (Guidelines section 15300.2 (c)) which removed the racing activity from the exemption. Additionally, the cour found that imposing mitigation measures to offset the possible significant adverse change in the environment caused by the activity will not cause the exemption to be applicable unless the mitigation measures result in the elimination of the possibility of a significant adverse change in the environment. The decision to allow stock car racing at a county fair in the first place could well call for some kind of CEQA analysis before starting that activity. Once the activity has been established, however, continuing the activity does not represent a change, and absent a significant change in the use and absent the existence of unusual circumstances. 
(3) Leasing of administrative and/or client service offices in newly constructed industrial parks.

Note:

Authority cited: Sections 21083 and 21087, Public Resources Code; Reference: Section 21084, Public Resources Code.

15328.

Small Hydroelectric Projects at Existing Facilities

Class 28 consists of the installation of hydroelectric generating facilities in connection with existing dams, canals, and pipelines where:

(a) The capacity of the generating facilities is 5 megawatts or le: $;$;

(b) Operation of the generating facilities will not change the flow regime in the affected stream. canal, or pipeline including but not limited to:

(1) Rate and volume of flow;

(2) Temperature;

(3) Amounts of dissolved oxygen to a degree that could adversely affect aquatic life; and

(4) Timing of release.

(c) New power lines to connect the generating facilities to existing power lines will not exceed one mile in length if located on a new right of way and will not be located adjacent to a wild or scenic river;

(d) Repair or reconstruction of the diversion structure will not raise the normal maximum surface elevation of the impoundment;

(e) There will be no significant upstream or downstream passage of fish affected by the project;

(f) The discharge from the power house will not be located more than 300 feet from the toe of the diversion structure;

(g) The project will not cause violations of applicable state or federal water quality standards;

(h) The project will not entail any construction on or alteration of a site included in or eligible for inclusion in the National Register of Historic Places; and

(i) Construction will not occur in the vicinity of any rare or endangered species.

Note:

Authority cited: Section 21083, Public Resources Code; Reference: Section 21084, Public Resources Code.

15329.

Cogeneration Class 29 consists of the installation of cogeneration equipment with a capacity of 50 Projects at Existing Facilities tion.

(a) At existing industrial facilities, the installation of cogeneration facilities will be exempt where it will:

(1) Result in no net increases in air emissions from the industrial facility, or will produce emissions lower than the amount that would require review under the new source review rules applicable in the county, and

(2) Comply with all applicable state, federal, and local air quality laws.

(b) At commercial and institutional facilities, the installation of cogeneration facilities will be exempt if the installation will:

(1) Meet all the criteria described in subsection (a);

(2) Result in no noticeable increase in noise to nearby residential structures;

(3) Be contiguous to other commercial or institutional structures.

Note:

Authority cited: Sections 21083 and 21087, Public Resources Code; Reference: Section 21084, Public Resources Code. 


\section{Lawrence Berkeley Laboratory NEPA/CEQA Compliance Checklist}

PROPOSAL NUMBER:

PRINCIPAL INVESTIGATOR:

PROJECT TITLE:

PROJECT LOCATION:

\section{NEPA}

Section I. Check one of the five boxes below to recommend appropriate NEPA documentation. If box 4 or 5 is checked, forward this form and project information to OPD, MS50A-4112.

1. NEPA DOCUMENTATION BY LBL NOT REQUIRED. All proposed activities, will take place at another DOE facility/site. DOE NEPA documentation, therefore, is the responbility of that facility.

2. COVERED UNDER DOE-APPROVED NEPA DOCUMENTATION. The proposed action is addressed in the following existing NEPA documentation. No further evaluation is necessary.

Environmental Assessment for the 1-2 GeV Synchrotron Radiation Source

- Construction of a Replacement Hazardous Waste Handling Facility at LBL

— DOE Categorical Exclusion LB-ER-

Other (Title:

3. APPENDIX A CATEGORICAL EXCLUSION. The proposed action falls under Categorical Exclusion A listed in Appendix A to Subpart D of 10 CFR 1021. A DOE determination is not required.

4. APPENDIX B CATEGORICAL EXCLUSION. The proposed action appears to fall under Categorical Exclusion B _ _ listed in Appendix B to Subpart D of 10 CFR 1021. A DOE determination will be requested by OPD.

5. ENVIRONMENTAL ASSESSMENT. None of the above applies, and therefore an Environmental Assessment may be required. A DOE determination will be requested by OPD.

Principal Investigator or Project Manager

Division NEPA/CEQA Coordinator

Division Director or designee

\section{Date}

$\overline{\text { Date }}$

Date 


\section{Lawrence Berkeley Laboratory NEPA/CEQA Compliance Checklist}

PROPOSAL NUMBER:

PRINCIPAL INVESTIGATOR:

PROJECT TITLE:

PROJECT LOCATION:

\section{CEOA}

Section II. Check one of the six boxes below to recommend appropriate CEQA documentation. If box 4,5 or 6 is checked, forward this form and project information to OPD, MS50A. 4112 .

1. CEQA DOCUMENTATION BY LBL NOT REQUIRED. All proposed activities will take place off-site (i.e. at locations other than LBL), and Regents approval is not required for the project.

2. COVERED UNDER A UCOP- OR REGENTS-APPROVED CEQA DOCUMENT. The proposed action is addressed in the following existing CEQA document. No further evaluation is required.

LBL Site Development Plan EIR/1992 Supplemental EIR

Initial Study for the 1-2 GeV Synchrotron Radiation Source

Other (Title:

3. EXEMPT FROM CEQA. The proposed action consists of one of the following and therefore is either not a "project" or does not have the potential for causing a significant effect on the environment. A UCOP determination is not required.
- routine maintenance
paper studies and/or computer modiling including data analysis and document preparation
other

4. CATEGORICAL EXEMPTION. The proposed project appears to fall under Categorical Exemption Class A UCOP determination will be requested by OPD.

The total project cost is $\$$

5. INITIAL STUDY. None of the above applies, and therefore preparation of an Initial Study may be required. A UCOP determination will be requested by OPD.

6. ENVIRONMENTAL IMPACT REPORT. It is known that the project will have a significant effect on the environment, and therefore an EIR may be required. A UCOP determination will be requested by OPD.

Principal Investigator or Project Manager

Division NEPA/CEQA Coordinator

Division Director or designee

\section{Date}

\section{Date}

\section{Date}




\section{UNIVERSITY OF CALIFORNIA}

Campus or Field Station
ENVIRONMENTAL IMPACT CLASSIFICATION

Project Account No.

Project Tale

For purposes of compliance with the California Environmental Quality Act of 1970 (CEQAA), and Amended University of Calitornia Procedures for Implementation of the CEQA, this project has been reviewed and initial dassified as indicated below. Please check (X) as appropriate. Include project description and appropriate local map.

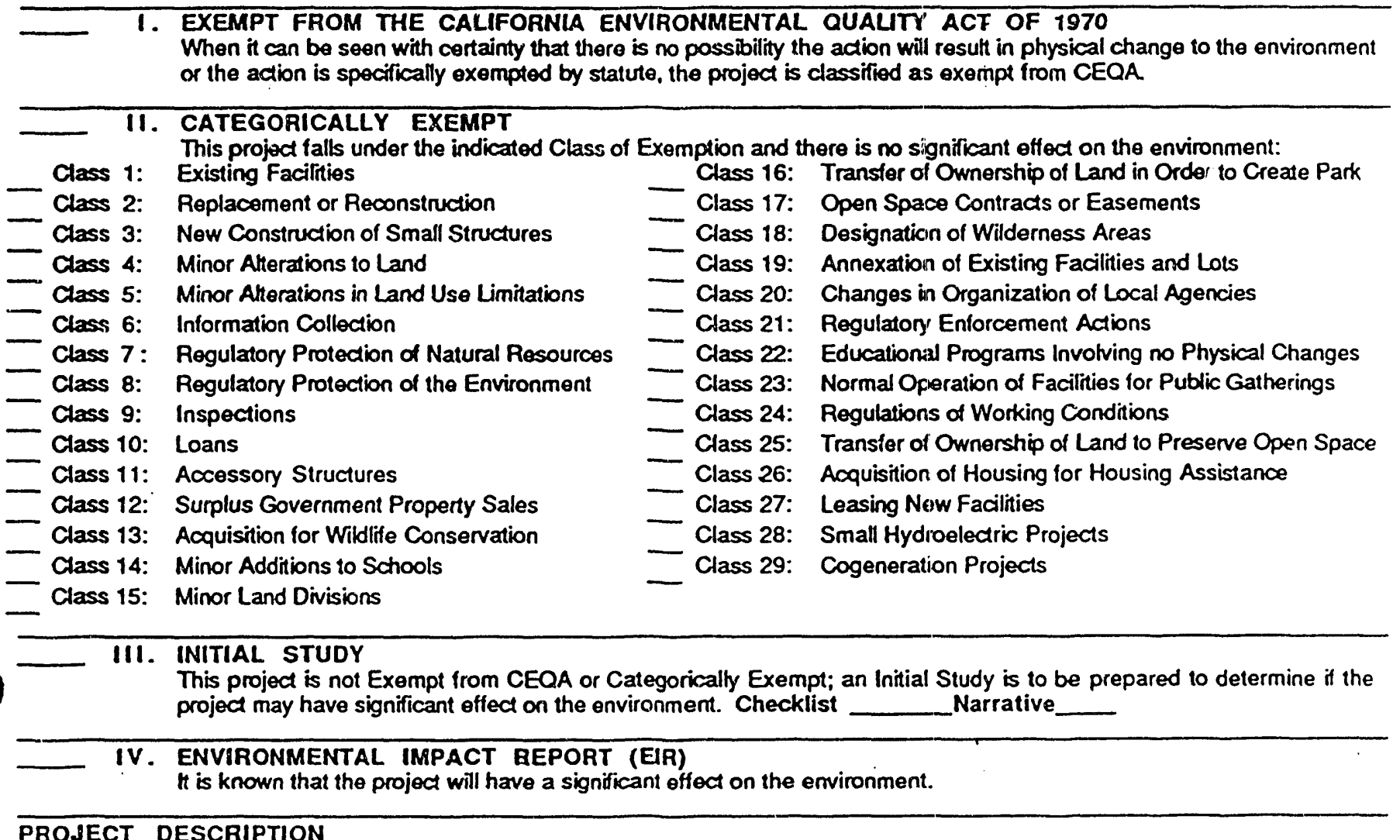

PROJECT DESCRIPTION

V. Does this project conform to the approved LRDP?
Are environmental effects of project adequately analyzed in certified
program EIR? and are the circumstances of the project essentially the
same as the circumstances under which the program ElR was prepared?
VI.
PII. OFFICE OF THE PRESIDENT
Concur with Classification




\section{Information For NEPA/CEQA/EH\&S Review for WORK TO BE CONDUCTED AT LBL (including the LBL Site and Donner and Calvin Labs at UCB)}

Principal Investigator: Proposal Title:

Division

1. Location of Work: Identify buildings and room number where the project will be performed.

2. Building/Room Use: Identify the current use of the room(s)/building. If not in current use, state its previous use.

3. Building/Room Alterations: Describe any building or rom alterations that would be necessary. Identify any associated environmental issues, e.g., generation and disposal of solid waste or asbestos.

4. Capital Equipment: Identify capital equipment that would be purchased for conducting the project. Describe the relative size of the equipment (e.g. can be placed on a desk top).

5. Hazardous Materials (including biological hazards): List names and quantities of any hazardous chemicals or radioactive materials that would be used.

6. Energy Sources: Identify equipment that contains stored energy and could result in a serious injury to a person (i.e. X-Ray Equipment, Lasers, RF Generators, etc.).

7. Safety Procedures: Briefly describe how materials identified above would be used. Identify safety procedures (titles/numbers) that are in place for the work that would be performed.

8. Airborne Emissions: Identity any anticipated airborne emissions resulting from the proposed work.

9. Chemical and Radioactive Waste Materials: Identify any waste chemicals or radioactive materials that would result from the proposed work.

10.Decontamination and Decommissioning (D\&D): Identify any activity/cost required for D\&D outside the scope of funding for this project, upon project completion. 


\section{Information For NEPA/CEQA Review \\ for OFF-SITE WORK TO BE CONDUCTED BY LBL PERSONNEL, FUNDED BY DOE, OR USING DOE EQUIPMENT (including UCB Campus and Other Off-Site Locations)}

Principal Investigator:

Division

Proposal Title:

(If work vill be conducted at more than one off-site location, provide separate information for each location)

1. Task Description: Describe that portion of the work that will be performed by LBL personnel at the off-site facility. (You may refer to specific pages of the proposal).

2. Location of Work: Irientify the building(s) where the LBL work will be performed. Is the building/rooms current use the same as the proposed use?

3. Building/Room Alterations: Describe any building or room alterations (including installation of new equipment) that would be necessary to conduct the proposed LBL work.

4. Environment, Safety, and Health: Identify any environment, safety, and health reviews that have been/will be conducted to ensure that LBL activities will not adversely affect workers or the environment.

5. Permits: Can the proposed LBL work be performed under existing regulatory permits? If not, identify any permits that are required for the proposed work.

6. Impacts to Sensitive Resources: If any portion of the work will be performed outdoors, will the proposed activities result in changes and/or disturbances to any of the following? Explain all yes and maybe answers.

yes no maybe

_ _ _ Threatened or endangered species or critical habitats

- _ Wetlands

_ - Archaeological resources

- - Surface water

- - Groundwater?

A5-2 


\section{GUIDANCE FOR WRITING PROJECT DESCRIPTIONS}

Adequaie project descriptions make the NEPA/CEQA processes more efficient, and thereby reduce costs and potential delays. The project description must address both construction and operations and should provide enough information to allow DOE/UC to determine if the project is categorically excluded/exempted from NEPA/CEQA. Typically, adequate project descriptions are about $1 / 2$ to 1 page long. If any of the below items do not apply, please indicate that the item is not applicable (N/A).

\section{Construction}

1. Scope and Cost. Identify the project, its purpose, and total estimated cost.

2. Location. Identify the location of proposed construction activities.

3. Construction Activities. Identify the proposed construction activities and purposes (e.g., two interior walls will be removed to provide space for..., or 50 feet of trenching will be required to connect...).

4. Ground Disturbance. For outdoor construction activities, describe the current ground cover and the type and extent of proposed ground disturbance.

5. EH\&S. Identify EH\&S concerns associated with construction (e.g., asbestos removal or disposal of hazardous waste), and how LBL will ensure safe and environmentally sound activities.

\section{Qperations}

1. Operations. Identify the proposed operations. Compare them to current operations in the building, if applicable.

2. Equipment. Identify the types of equipment that will be used (provide only enough detail to allow DOE/UC to understand the potential hazards, or absence of hazards). Is the equipment bench scale? Compare it to equipment currently being used in the building and room, if applicable.

3. Hazardous Material. Identify the hazardous materials that will be used, and state if they are in current use in the building and room.

4. Hazardous Waste. Identify the hazardous wastes that will be generated, and state if these wastes are currently being generated.

5. Safety Procedures. State whether an OSP exists for proposed operations, or if a new or revised OSP will be required. (Note: if a new or revised OSP will be needed, the activities may not qualify as a categorical exclusion/ exemption.)

6. Permits. State whether any new or amended environmental permits will be required for the operations. (Note: if a new or amended permit will be needed, the activities may not qualify as a categorical exclusion/ exemption.) 


\begin{tabular}{|c|c|c|c|}
\hline \multicolumn{4}{|c|}{$\begin{array}{l}\text { TYPICAL ENVIRONMENTAL ASSESSMENT } \\
\text { REVIEW AND APPROVAL SCHEDULE }\end{array}$} \\
\hline Item & Date & Action & Lead \\
\hline 1 & Day 1 & LBL submits pre-decisional draft EA to DOE/SF for review & LBL \\
\hline 2 & Day 20 & BSO submits comments on pre-decisional draft to LBL & BSO \\
\hline 3 & Day 22 & $\begin{array}{l}\text { L.BL incorporates comments and resubmits pre-decisional draft to BSO for } \\
\text { transmittal to ER-8 }\end{array}$ & LBL \\
\hline 4 & Day 60 & DOE/SF submits additional comments to LBL & BSO \\
\hline 5 & Day 72 & LBL incorporates comments and resubmits to BSO & LBL \\
\hline 6 & Day 75 & BSO sends pre-decisional EAFONSI to ER-8 for informal review. & BSO \\
\hline 7 & Day 102 & ER-8 submits informal comments 10 BSO and LBL & ER-8 \\
\hline 8 & Day 112 & LBL incorporates comments and sends revision to SF & LBL \\
\hline 9 & Day 124 & SF sends draft EAFONSI officially to ER-1 for EH approval & BSO \\
\hline 10 & Day 135 & $\begin{array}{l}\text { ER-1 forwards draft EA to EH-1 for approval and final authority to go to } \\
\text { State (note: ER-8 submitted draft EA informally to EH-25) }\end{array}$ & ER-1 \\
\hline 11 & Day 225 & EH-25 and General Counsel complete review and send comments to ER-1 & $\begin{array}{l}E H-25 \\
\& G C\end{array}$ \\
\hline 12 & Day 225 & $\begin{array}{l}\text { If EH-25 comments are minor, draft EA pre-approved for State coordination } \\
\text { upon incorporation of comments. }\end{array}$ & $\begin{array}{l}\text { ER-8 \& } \\
\text { ER-70 }\end{array}$ \\
\hline 13 & Day 228 & HQ comments on draft EA sent to SF/LBL & ER-8 \\
\hline 14 & Day 247 & LBL incorporates comments and resubmits draft EAFONSI to SF & LBL \\
\hline 15 & Day 254 & SF forwards draft EAFONSI to OER NCO & BSO \\
\hline 16 & Day 268 & ER-1 sends EA to State & ER-1 \\
\hline 17 & Day 298 & State responds. HQ forwards State comments (if any) to SF. & ER-8 \\
\hline 18 & Day 298 & SF forwards comments (if any) to LBL & BSO \\
\hline 19 & Day 310 & LBL incorporates comments (if any) and resubmits EAFONSI to SF (Final) & LBL \\
\hline 20 & Day 317 & BSO submits Final EAFONSI to ER-8 & BSO \\
\hline 21 & Day 326 & ER-8 forwards Final EAFONSI to EH-25 for approval & ER-8 \\
\hline 22 & Day 336 & $\begin{array}{l}\text { Final EH review completed, and Final EAFONSI approved contingent upon } \\
\text { incorporation of comments, if any. Comments forwarded to OER. }\end{array}$ & $\begin{array}{l}E H-18 \\
E H-25\end{array}$ \\
\hline 23 & Day 343 & $\begin{array}{l}\text { ER forwards comments to SF/LBL, LBL incorporates comments and } \\
\text { resubmits Final EAFFONSI to SF, SF forwards to ER. }\end{array}$ & $\begin{array}{l}\text { ER-8 } \\
\text { BSO } \\
\text { LBL }\end{array}$ \\
\hline 24 & Day 354 & ER-8 returns approved EAVONSI to SF & ER-8 \\
\hline 25 & Day $354^{*}$ & SF notifies LBL of decision & BSO \\
\hline 26 & Day 365 & $\begin{array}{l}\text { DOE notifies public of availability of EA and FONSI and sends record of } \\
\text { distribution to EH-25 }\end{array}$ & $\mathrm{EH}-1$ \\
\hline
\end{tabular}



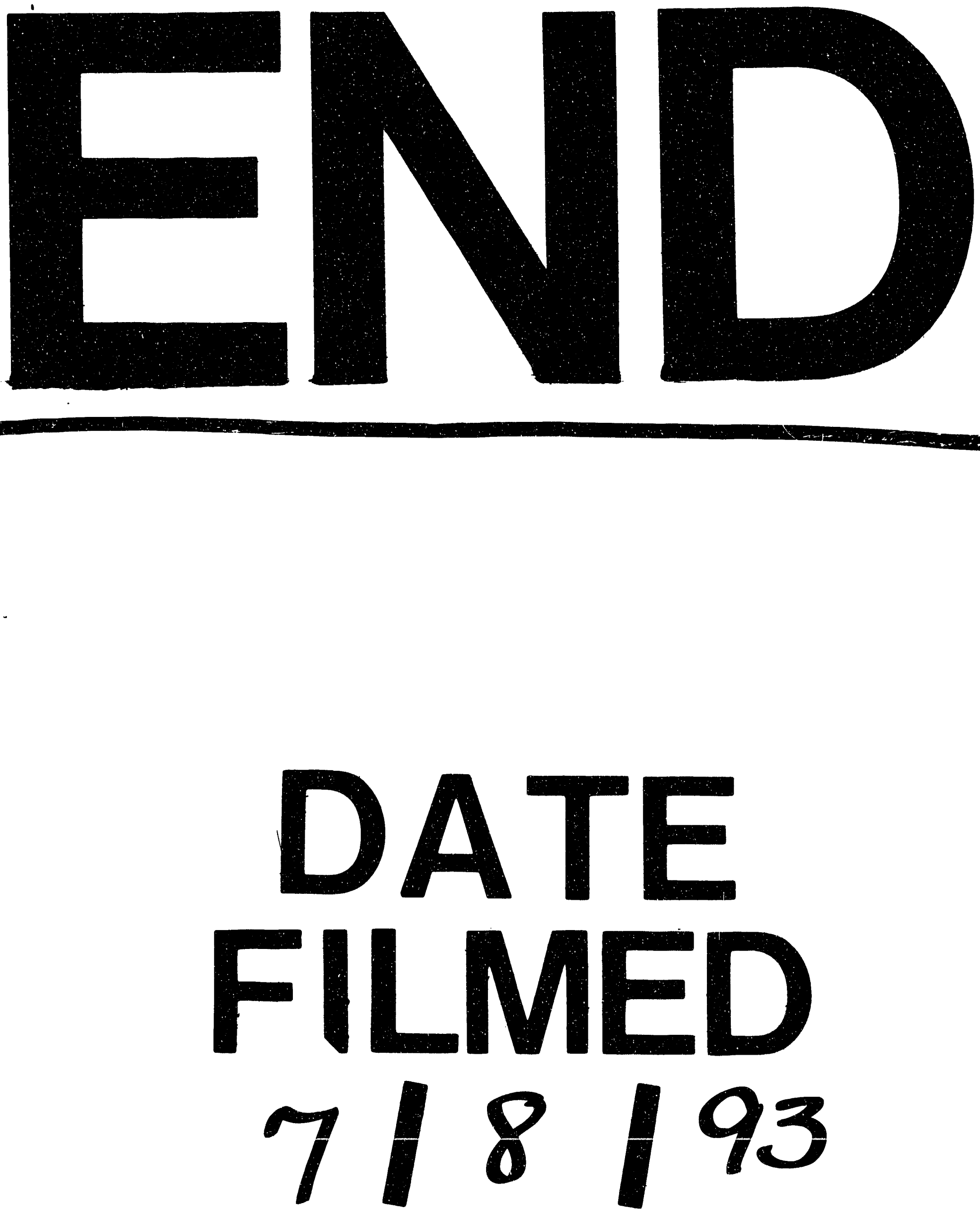
